\title{
Synthesis and preclinical evaluation of DOTAGA- conjugated PSMA ligands for functional imaging and endoradiotherapy of prostate cancer
}

\author{
Martina Weineisen ${ }^{1 *}$, Jakub Simecek ${ }^{1}$, Margret Schottelius ${ }^{1}$, Markus Schwaiger ${ }^{2}$ and Hans-Jürgen Wester ${ }^{1}$
}

\begin{abstract}
Background: Due to its high expression in prostate cancer, PSMA (prostate-specific membrane antigen) represents an ideal target for both diagnostic imaging and endoradiotherapeutic approaches. Based on a previously published highly specific PSMA ligand ([ $\left.{ }^{68} \mathrm{Ga}\right] \mathrm{DOTA}-\mathrm{FFK}(\mathrm{Sub}-\mathrm{KuE})$ ), we developed a corresponding metabolically stable 1,4,7,10-tetraazacyclododececane,1-(glutaric acid)-4,7,10-triacetic acid (DOTAGA) construct for theranostic treatment of prostate cancer.
\end{abstract}

Methods: All ligands were synthesized by a combined solid phase and solution phase synthesis strategy. The affinity of the ${ }^{\text {nat }}$ gallium and lutetium complexes to PSMA and the internalization efficiency of the radiotracers were determined on PSMA-expressing LNCaP cells. The ${ }^{68} \mathrm{Ga}$ - and ${ }^{177}$ Lu-labelled ligands were further investigated for lipophilicity, binding specificity, metabolic stability, as well as biodistribution and $\mu$ PET in LNCaP-tumour-bearing mice.

Results: Radiochemical yields for ${ }^{68} \mathrm{Ga}\left(3 \mathrm{nmol}, 5.0 \mathrm{M} \mathrm{NaCl} / 2.7 \mathrm{M} \mathrm{HEPES}\right.$ (approximately 5/1), pH 3.5 to 4.5, 5 min, $95^{\circ} \mathrm{C}$ ) and ${ }^{177} \mathrm{Lu}$ labelling $\left(0.7 \mathrm{nmol}, 0.1 \mathrm{M} \mathrm{NH}_{4} \mathrm{OAc}, \mathrm{pH} 5.5,30 \mathrm{~min}, 95^{\circ} \mathrm{C}\right)$ were almost quantitative, resulting in specific activities of 250 to $300 \mathrm{GBq} / \mu \mathrm{mol}$ for the ${ }^{68} \mathrm{Ga}$ analogues and $38 \mathrm{GBq} / \mu \mathrm{mol}$ for ${ }^{177} \mathrm{Lu}$ complexes. Due to metabolic instability of L-amino acid spacers, D-amino acids were implemented resulting in a metabolically stable DOTAGA ligand. Compared to the DOTA ligand, the DOTAGA derivatives showed higher hydrophilicity $(\log P=-3.6 \pm 0.1$ and $-3.9 \pm 0.1$ for ${ }^{68} \mathrm{Ga}$ and ${ }^{177} \mathrm{Lu}$, respectively) and improved affinity to PSMA resulting in an about twofold increased specific internalization of the ${ }^{68} \mathrm{Ga}$ - and ${ }^{177}$ Lu-labelled DOTAGA analogue. Especially, $\left.{ }^{68} \mathrm{Ga}\right] D O T A G A-f f k(S u b-K u E)$ exhibits favourable pharmacokinetics, low unspecific uptake and high tumour accumulation in LNCaP-tumour-bearing mice.

Conclusions: The pair of diagnostic/therapeutic PSMA-ligands $\left[{ }^{68} \mathrm{Ga} /{ }^{177} \mathrm{Lu}\right] \mathrm{DOTAGA}-\mathrm{ffk}($ Sub-KuE) possess remarkable potential for the management of prostate cancer.

Keywords: Prostate cancer; Theranostic; Endoradiotherapy; PET; PSMA; Prostate-specific membrane antigen; PSMA

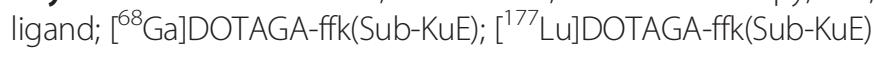

\section{Background}

Prostate-specific membrane antigen (PSMA, EC 3.4.17.21, synonym: glutamate carboxypeptidase II) is an extracellular hydrolase whose catalytic centre comprises two zinc(II) ions with a bridging hydroxido ligand [1]. It is highly upregulated in metastatic and hormone-refractory prostate carcinomas, but its endogenous expression has also been

\footnotetext{
* Correspondence: martina.weineisen@tum.de

'Pharmaceutical Radiochemistry, Technical University Munich,

Walther-Meißner-Str. 3, 85748 Garching, Germany

Full list of author information is available at the end of the article
}

reported in kidneys, salivary glands, small intestine, brain and, to a low extent, also in healthy prostate tissue $[2,3]$. In the intestine, PSMA facilitates absorption of folate by conversion of pteroylpoly- $\gamma$-glutamate to the pteroylglutamate (folate) [4]. In the brain, it hydrolyses $N$-acetyl-Laspartyl-L-glutamate (NAAG) to $\mathrm{N}$-acetyl-L-aspartate and glutamate [5]. The enzymatic function of PSMA in normal and diseased prostate has not been clarified yet [6]. However, due to its overexpression on prostate cancer cells, PSMA represents an excellent target for molecular imaging and targeted radiotherapy of prostate cancer. 
Since the discovery of urea-based PSMA inhibitors in 2001 [7], a variety of PSMA-targeted radioligands for imaging of prostate cancer were developed. The first PSMA inhibitors radiolabelled with ${ }^{11} \mathrm{C},{ }^{18} \mathrm{~F}$ and ${ }^{123 / 125} \mathrm{I}$ used the X-urea-Glu (XuE)-scaffold (Figure 1, [8-13]). All of them show high affinity to PSMA and specific tumour accumulation, demonstrating the suitability of this class of compounds as imaging probes. Subsequently, ${ }^{99 \mathrm{~m}} \mathrm{Tc}$-labelled analogues $[14,15]$ were developed to provide a generator produced PSMA imaging agent for SPECT.

Recently, it has been demonstrated that the affinity of KuE-derived inhibitors is enhanced by extending the KuE-binding unit by an aromatic moiety, presumably due to an additional inhibitor-enzyme interaction via $\pi /$ $\pi$-stacking of the additional aromatic residues with a remote arene-binding pocket [16]. There is apparently an optimal distance between the KuE-inhibitor component and the additional arene moiety, leading to an enhancement of PSMA affinity $\left(K_{D}=13.8 \mathrm{nM}\right)$ by a factor of up to 5 [15].

These findings were recently integrated into the design of ${ }^{68} \mathrm{Ga}$-labelled PSMA ligands (Figure 2), such as $\left[{ }^{68} \mathrm{Ga}\right]$ DOTA-FFK(Sub-KuE) [17] and $\left[{ }^{68} \mathrm{Ga}\right]$ HBED-CC-Ahx-KuE [18]. Compared to $\left[{ }^{68} \mathrm{Ga}\right] D O T A-F F K(S u b-K u E), \quad\left[{ }^{68} \mathrm{Ga}\right]$ HBED-CC-Ahx-KuE showed higher tumour accumulation and improved imaging contrast [18]. Unfortunately, the HBED-CC chelator ( $N, N^{\prime}$-bis[2-hydroxy-5-(carboxyethyl) benzyl] ethylenediamine- $N, N^{\prime}$-diacetic acid) is not suitable for radiolabelling with therapeutic radiometals, whereas 1,4,7,10-tetraazacyclododecane-1,4,7,10-tetraacetic acid (DOTA) and its analogues form stable complexes with a broad range of radiometals, for therapy most importantly ${ }^{90} \mathrm{Y}$ and ${ }^{177} \mathrm{Lu}$. Given the high expression of PSMA on the majority of prostate cancers, the availability of high-affinity PSMA-targeted probes, labelled with therapeutic radioisotopes, offers promising perspectives for PSMA-targeted endoradiotherapy.

Monoclonal anti-PSMA-antibodies labelled with therapeutic radionuclides such as ${ }^{131} \mathrm{I},{ }^{90} \mathrm{Y}$ and ${ }^{177} \mathrm{Lu}$, which are currently being evaluated in clinical trials (clinicaltrials.gov Identifier: NCT00006380, NCT00081172) already demonstrate promising tumour targeting, acceptable toxicity and therapeutic efficiency in humans [19-22].

Amongst the currently available small-molecule PSMA inhibitors, only $\left[{ }^{131} \mathrm{I}\right] \mathrm{MIP}-1375$ [23] and $\left.{ }^{[131} \mathrm{I}\right] \mathrm{MIP}-1466$ [24] (Figure 1) have been evaluated in therapy studies so far. In LNCaP-tumour-bearing nude mice, $\left[{ }^{131} \mathrm{I}\right] \mathrm{MIP}-$ 1375 inhibited tumour growth in a time- and dosedependent manner. First, human applications of $\left[{ }^{131} \mathrm{I}\right]$ MIP-1095/1466 revealed promising therapy response with moderate side effects [25]. The structurally corresponding diagnostics, ${ }^{123}$ I-labelled analogues $\left[{ }^{123} \mathrm{I}\right] \mathrm{MIP}-$ 1072 and $\left[{ }^{123} \mathrm{I}\right] \mathrm{MIP}-1095$, were shown to possess suitable characteristics for SPECT imaging. However, these compounds are comparably lipophilic $(\operatorname{cog} P=0.20$ and 1.97 , respectively [25]), and their compact structure complicates further optimization of PSMA affinity and pharmacokinetics. Furthermore, PET imaging is only possible using ${ }^{124} \mathrm{I}$, a suboptimal PET-radionuclide with respect to resolution and dosimetry.

In contrast, radiometalated analogues based on the FFK(Sub-KuE)-scaffold represent a much more flexible and finely adjustable backbone for the development of KuE-based PSMA inhibitors, that allow labelling with both diagnostic and therapeutic radionuclides, e.g. ${ }^{68} \mathrm{Ga}$ for PET imaging and ${ }^{177} \mathrm{Lu} /{ }^{90} \mathrm{Y}$ for therapy after conjugation of DOTA. However, in order to further facilitate

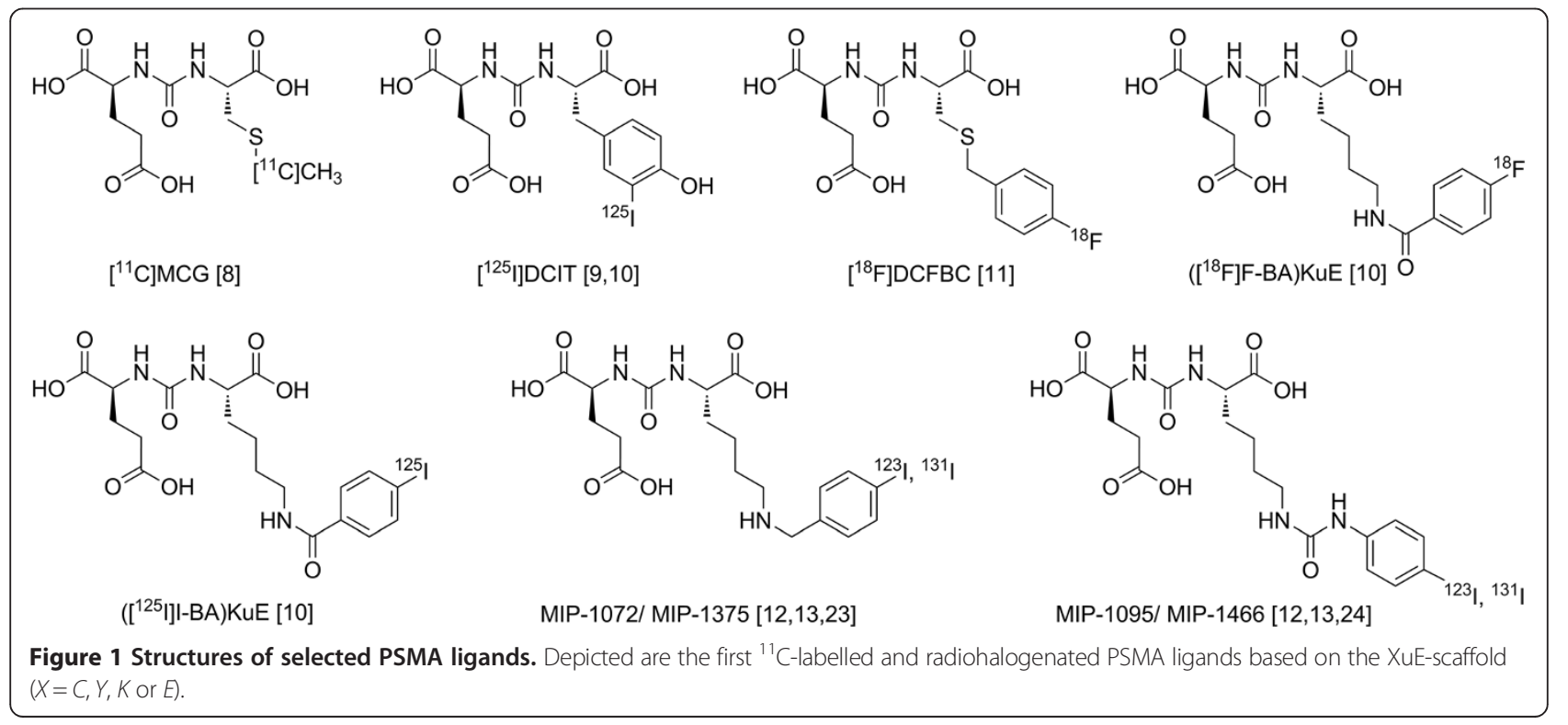



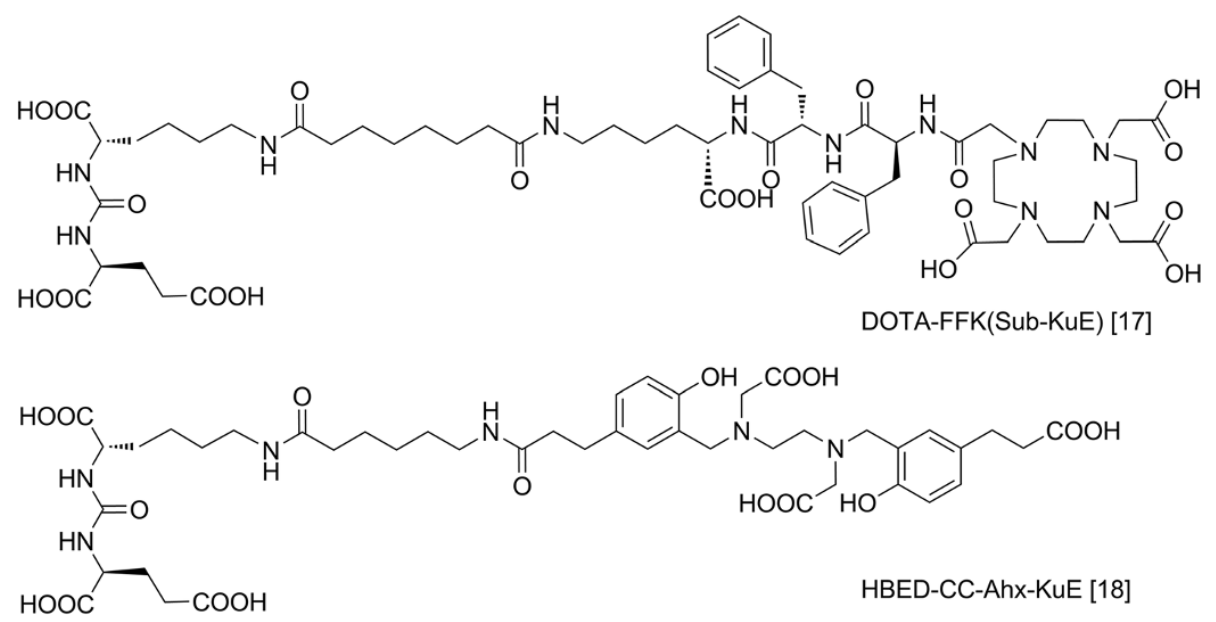

Figure 2 Previously reported PSMA ligands for ${ }^{68} \mathrm{Ga}$ labelling $[17,18]$. Both compounds were included as references in this study.

the labelling procedure for ${ }^{177} \mathrm{Lu}$ and ${ }^{90} \mathrm{Y}$, improve ligand pharmacokinetics, and potentially obtain radiometalated derivatives with higher affinity, we substituted DOTA in DOTA-FFK(Sub-KuE) by 1,4,7,10-tetraazacyclodocecane,1(glutaric acid)-4,7,10-triacetic acid (DOTAGA) [26,27]. Improved affinities, higher tumour uptake and faster kidney clearance have already been observed for the ${ }^{68} \mathrm{Ga}$ complex (one free carboxylate) compared to the ${ }^{90} \mathrm{Y}$-complex (all carboxylates coordinated) of DOTA-coupled somatostatin analogues before [28].

Consequently, we evaluated and compared the respective ${ }^{68 / \mathrm{nat}} \mathrm{Ga}$ - and ${ }^{177 / \mathrm{nat}} \mathrm{Lu}$-DOTAGA analogues of FFK (Sub-KuE) and ffk(Sub-KuE) in terms of PSMA affinity, uptake in PSMA positive tumour cells, metabolic stability, in vivo biodistribution and $\mu$ PET imaging. The previously described DOTA analogues [17] and $\left[{ }^{68} \mathrm{Ga}\right]$ HBED-CCAhx-KuE [18] were also included to allow direct comparability of our results with the data in the literature.

\section{Methods \\ General}

Fmoc-(9-fluorenylmethoxycarbonyl-) and all other protected amino acid analogues were purchased from Iris Biotech (Marktredwitz, Germany) or Bachem (Bubendorf, Switzerland). Tritylchloride polystyrene (TCP) resin was obtained from PepChem (Tübingen, Germany). The chelators DOTA-tris- $t$ Bu-ester and DOTAGA-anhydride were purchased from Chematech (Dijon, France). Solvents and all other organic reagents were purchased from SigmaAldrich (Munich, Germany) or CLN (Freising, Germany). Solid phase peptide synthesis was carried out manually using an Intelli-Mixer syringe shaker (Neolab, Heidelberg, Germany). Analytical reversed-phase high performance liquid chromatography (RP-HPLC) was performed on a Nucleosil $100 \mathrm{C} 18(5 \mu \mathrm{m}, 125 \times 4.0 \mathrm{~mm})$ column (CS $\mathrm{GmbH}$, Langerwehe, Germany) using a Sykam gradient
HPLC System (Sykam GmbH, Eresing, Germany). The peptides were eluted applying different gradients of $0.1 \%(v / v)$ trifluoroacetic acid (TFA) in $\mathrm{H}_{2} \mathrm{O}$ (solvent A) and $0.1 \%$ TFA $(v / v)$ in acetonitrile (solvent B) at a constant flow of $1 \mathrm{~mL} / \mathrm{min}$ (specific gradients are cited in the text). UV detection was performed at $220 \mathrm{~nm}$ using a $206 \mathrm{PHD}$ UV-Vis detector (Linear ${ }^{\mathrm{Tm}}$ Instruments Corporation, Reno, USA). Both retention times $t_{R}$ as well as the capacity factors $K$ are cited in the text. Preparative RP-HPLC was performed on the same HPLC system using a Multospher 100 RP 18-5 $(250 \times 20 \mathrm{~mm})$ column (CS GmbH, Langerwehe, Germany) at a constant flow of $9 \mathrm{~mL} / \mathrm{min}$. Radio-HPLC of the radioiodinated reference ligand was carried out using a Nucleosil $100 \mathrm{C} 18(5 \mu \mathrm{m}, 125 \times 4.0 \mathrm{~mm})$ column. For radioactivity detection, the outlet of the UV-photometer was connected to a $\mathrm{NaI}(\mathrm{Tl})$ well-type scintillation counter from EG\&G Ortec (Munich, Germany). Analysis of ${ }^{68} \mathrm{Ga}$-labelled compounds was done as described previously [29]. ESI-mass spectra were acquired on a Varian 500-MS IT mass spectrometer (Agilent Technologies, Santa Clara, USA).

\section{Synthesis of carboxyl-protected Lys-urea-Glu-core (KuE)}

(S)-di-tert-butyl 2-(1H-imidazole-1-carboxamido)pentanedioate (1) was synthesized as described previously [12]. $\mathrm{HPLC}(10 \%$ to $90 \% \mathrm{~B}$ in $15 \mathrm{~min}): t_{R}=12.2 \mathrm{~min} ; K^{\prime}=$ 5.78. Calculated monoisotopic mass for $\mathbf{1}\left(\mathrm{C}_{17} \mathrm{H}_{27} \mathrm{~N}_{3} \mathrm{O}_{5}\right)$ : 353.4; found: $m / z=376.0[\mathrm{M}+\mathrm{Na}]^{+}$.

$\mathrm{Cbz}-(\mathrm{OtBu}) \mathrm{KuE}(\mathrm{OtBu})_{2}$ (2): A solution of $3.40 \mathrm{~g}$ (9.64 mmol, 1.0 eq) $\mathbf{1}$ in $45 \mathrm{~mL} \mathrm{1,2-dichloroethane}$ (DCE) was cooled to $0^{\circ} \mathrm{C}$, and $2.69 \mathrm{~mL}(19.28 \mathrm{mmol}$, $2.0 \mathrm{eq})$ of triethylamine (TEA), and $3.59 \mathrm{~g}(9.64 \mathrm{mmol}$, $1.0 \mathrm{eq})$ of $\mathrm{Cbz}-\mathrm{Lys}-\mathrm{OtBu} \cdot \mathrm{HCl}$ was added under vigorous stirring. The reaction mixture was heated to $40^{\circ} \mathrm{C}$ overnight. The solvent was removed in vacuo, and the crude product was purified via silica gel flash-chromatography 
using an eluent mixture of ethyl acetate/hexane/TEA $(500 / 500 / 0.8(\mathrm{v} / \mathrm{v} / \mathrm{v}))$. Upon solvent evaporation, $4.80 \mathrm{~g}$ of 2 were obtained as a colourless, sticky oil (yield: $80 \%$ based on L-di-tert-butyl glutamate $\cdot \mathrm{HCl})$. HPLC (40\% to $100 \% \mathrm{~B}$ in $15 \mathrm{~min}$ ): $t_{R}=14.3 \mathrm{~min} ; K^{\prime}=8.53$. Calculated monoisotopic mass for $2\left(\mathrm{C}_{32} \mathrm{H}_{51} \mathrm{~N}_{3} \mathrm{O}_{9}\right)$ : 621.8; found: $m / z=622.2[\mathrm{M}+\mathrm{H}]^{+}, 644.3[\mathrm{M}+\mathrm{Na}]^{+}$.

$(\mathrm{OtBu}) \mathrm{KuE}(\mathrm{OtBu})_{2}(3)$ : For $\mathrm{Cbz}$ deprotection, $6.037 \mathrm{~g}$ (9.71 mmol, $1.0 \mathrm{eq})$ of 2 was dissolved in $150 \mathrm{~mL}$ of ethanol (EtOH), and $0.6 \mathrm{~g}(1.0 \mathrm{mmol}, 0.1 \mathrm{eq})$ of Palladium on activated charcoal (10\%) was added. After purging the flask with $\mathrm{H}_{2}$, the solution was stirred overnight under light $\mathrm{H}_{2}$-pressure (balloon). The crude product was filtered through Celite, the solvent was evaporated in vacuo, and the desired product was obtained as a waxy solid (4.33 g, 91.5\% yield). HPLC (10\% to $90 \%$ B in $15 \mathrm{~min}): t_{R}=12.6 \mathrm{~min} ; K^{\prime}=6.41$. Calculated monoisotopic mass for $3\left(\mathrm{C}_{24} \mathrm{H}_{45} \mathrm{~N}_{3} \mathrm{O}_{7}\right)$ : 487.6; found: $m / z=488.3$ $[\mathrm{M}+\mathrm{H}]^{+}, 510.3[\mathrm{M}+\mathrm{Na}]^{+}$.

\section{Synthesis of protected Sub-KuE conjugate}

NHS-Sub-(OtBu)KuE(OtBu) $)_{2}$ (4): 3 (40 mg, $0.08 \mathrm{mmol}$, $1 \mathrm{eq})$ was dissolved in $500 \mu \mathrm{L} N, N$-dimethylformamide (DMF), and $57 \mu \mathrm{L}(0.41 \mathrm{mmol}, 5 \mathrm{eq})$ of TEA was added. This solution was added dropwise (within $30 \mathrm{~min}$ ) to a solution of $33.2 \mathrm{mg}(0.09 \mathrm{mmol}, 1.1 \mathrm{eq})$ of disuccinimidyl suberate (DSS). After stirring for an additional $2 \mathrm{~h}$ at room temperature (RT), the reaction mixture was concentrated in vacuo, diluted with ethyl acetate and extracted with water (twice). The organic phase was dried over $\mathrm{Na}_{2} \mathrm{SO}_{4}$, filtered and evaporated to dryness. Due to sufficient purity of the crude $\mathbf{4}$, it was used for the following reaction step without further purification. HPLC (10\% to $90 \% \mathrm{~B}$ in $15 \mathrm{~min}): t_{R}=16.9 \mathrm{~min} ; K^{\prime}=8.39$. Calculated monoisotopic mass for $4\left(\mathrm{C}_{36} \mathrm{H}_{60} \mathrm{~N}_{4} \mathrm{O}_{12}\right)$ : 740.4; found: $m / z=741.2[\mathrm{M}+\mathrm{H}]^{+}, 763.4[\mathrm{M}+\mathrm{Na}]^{+}$.

\section{Synthesis of peptidic spacers}

Fmoc-L-Phe-L-Phe-L-Lys(Boc) (Fmoc-FFK, 5) and Fmoc-D-Phe-D-Phe-D-Lys(Boc) (Fmoc-ffk, 6): Fmoc-Lys (Boc)-OH was coupled to TCP resin according to a previously published method [30]. Briefly, Fmoc-Lys (Boc)-OH (1.5 eq) was dissolved in dry dichloromethane (DCM), and N,N-diisopropylethylamine (DIPEA) (1.25 eq) was added. Dry TCP resin was suspended and stirred at RT for $5 \mathrm{~min}$. Another 2.5 eq of DIPEA was added, and stirring was continued for $90 \mathrm{~min}$. Then, $1 \mathrm{~mL}$ methanol $(\mathrm{MeOH})$ per gram resin was added to cap unreacted Tritylchloride groups. After $15 \mathrm{~min}$, the resin was filtered off, washed twice with DCM, DMF and $\mathrm{MeOH}$, respectively, and dried in vacuo. Final load of resin-bound Fmoc-Lys(Boc)-OH was calculated from the weight difference.
Assembly of the peptide sequence $\mathrm{H}_{2} \mathrm{~N}$-Phe-Phe- on resin-bound Lys(Boc) was performed according to a standard Fmoc-protocol using 1.5 eq of 1-hydroxybenzotriazole (HOBt) and $O-\left(1 \mathrm{H}\right.$-benzotriazol-1-yl)- $N, N, N, N^{\top}$-tetramethyluronium-tetrafluoroborate (TBTU) as coupling reagents and 4.5 eq DIPEA. After coupling of the last amino acid, the resin was washed, dried and stored in a desiccator until further functionalization.

\section{Coupling of chelating moiety}

Fmoc-Phe-Phe-Lys(Boc)-TCP resin was allowed to preswell in $N$-methyl-pyrrolidon (NMP) for $30 \mathrm{~min}$. After cleavage of the N-terminal Fmoc-protecting group using $20 \%$ piperidine in DMF $(v / v)$, the resin was washed eight times with NMP. The coupling of the respective chelators is described below. Cleavage from the resin $(2 \times 30 \mathrm{~min})$ and concomitant $t \mathrm{Bu}$-deprotection was performed using a mixture $(v / v / v)$ of $95 \%$ TFA, $2.5 \%$ triisobutylsilane (TIBS) and $2.5 \%$ water. The combined product solutions were then concentrated, the crude peptide was precipitated using diethyl ether and was dried in vacuo. Due to sufficient purity of the crude products, they were used for the following reaction step without further purification.

DOTA-Phe-Phe-Lys (DOTA-FFK, 7) [17]: For $38 \mu \mathrm{mol}$ of resin-bound peptide, $33 \mathrm{mg}$ of DOTA-tris- $t$ Bu-ester (57 $\mu \mathrm{mol}, 1.5 \mathrm{eq}), 108 \mathrm{mg}$ of O-(7-azabenzotriazol-1-yl)- $N$, $N, N^{\prime}, N^{\prime}$-tetramethyluronium hexafluorophosphate (HATU; $0.28 \mu \mathrm{mol}, 5 \mathrm{eq})$ and $87 \mu \mathrm{L}$ of DIPEA ( $570 \mu \mathrm{mol}, 15 \mathrm{eq})$ in NMP were added to the resin. After $72 \mathrm{~h}$ of shaking, the resin was washed with NMP and DCM. HPLC (10\% to $90 \% \mathrm{~B}$ in $15 \mathrm{~min}): t_{R}=8.2 \mathrm{~min} ; K^{\prime}=4.13$. Calculated monoisotopic mass for $7\left(\mathrm{C}_{40} \mathrm{H}_{58} \mathrm{~N}_{8} \mathrm{O}_{11}\right): 826.4$; found: $m / z=$ $827.3[\mathrm{M}+\mathrm{H}]^{+}, 849.3[\mathrm{M}+\mathrm{Na}]^{+}, 414.2[\mathrm{M}+2 \mathrm{H}]^{2+}$.

DOTAGA-Phe-Phe-Lys (DOTAGA-FFK, 8 and DOTAGAffk, 9): For $0.27 \mathrm{mmol}$ peptide-bound resin, $190 \mathrm{mg}$ DOTAGA-anhydride (0.42 mmol, $1.5 \mathrm{eq})$ and $470 \mu \mathrm{L}$ DIPEA (2.7 mmol, $10 \mathrm{eq}$ ) in NMP were added to the resin. After $18 \mathrm{~h}$ of shaking, the resin was washed with NMP and DCM. HPLC (10\% to $90 \% \mathrm{~B}$ in $15 \mathrm{~min}): t_{R}=$ $10.6 \mathrm{~min} ; K^{\prime}=5.63$. Calculated monoisotopic mass for $\mathbf{8}$ and $9\left(\mathrm{C}_{43} \mathrm{H}_{62} \mathrm{~N}_{8} \mathrm{O}_{13}\right): 898.4$; found: $m / z=899.4[\mathrm{M}+\mathrm{H}]^{+}$, 921.4 $[\mathrm{M}+\mathrm{Na}]^{+}, 450.2[\mathrm{M}+2 \mathrm{H}]^{2+}$.

\section{Condensation of the chelator-conjugated peptides and the PSMA binding motif}

DOTA-FFK(Sub-KuE) (10) [17]: To a solution of 7 (15 mg, $18 \mu \mathrm{mol}, 1 \mathrm{eq})$ and TEA $(13 \mu \mathrm{L}, 90 \mu \mathrm{mol}, 5 \mathrm{eq})$ dissolved in $600 \mu \mathrm{L}$ of DMF was slowly added $13 \mathrm{mg}$ of $4(18 \mu \mathrm{mol}, 1 \mathrm{eq})$ dissolved in $400 \mu \mathrm{L}$ of DMF. After stirring for $2 \mathrm{~h}$ at $\mathrm{RT}$, the reaction mixture was evaporated to dryness. Subsequent removal of $t \mathrm{Bu}$-protecting groups was carried out by dissolving the crude product in TFA and stirring for $40 \mathrm{~min}$. After precipitation in diethyl ether, the crude product was dissolved in water and 
purified using preparative RP-HPLC (25\% to $40 \% \mathrm{~B}$ in $20 \mathrm{~min})$. HPLC $(10 \%$ to $90 \% \mathrm{~B}$ in $15 \mathrm{~min}): t_{R}=$ $10.3 \mathrm{~min} ; K^{\prime}=5.44$. Calculated monoisotopic mass for $10\left(\mathrm{C}_{60} \mathrm{H}_{89} \mathrm{~N}_{11} \mathrm{O}_{20}\right): 1,283.6$; found: $m / z=1,284.5[\mathrm{M}+\mathrm{H}]^{+}$, $1,306.7[\mathrm{M}+\mathrm{Na}]^{+}, 642.8[\mathrm{M}+2 \mathrm{H}]^{2+}$.

DOTAGA-FFK(Sub-KuE) (11) and DOTAGA-ffk(SubKuE) (12): Either 8 or 9 (21 mg, $30 \mu \mathrm{mol}, 1 \mathrm{eq})$ was added to TEA ( $21 \mu \mathrm{L}, 150 \mu \mathrm{mol}, 5 \mathrm{eq})$ and $27 \mathrm{mg}$ of 4 (30 $\mu \mathrm{mol}, 1 \mathrm{eq})$ as described for 10. HPLC (10\% to $90 \%$ $\mathrm{B}$ in $15 \mathrm{~min}$ ): $t_{R}=9.7 \mathrm{~min} ; K^{\prime}=4.11$. Calculated monoisotopic mass for 11 and $12\left(\mathrm{C}_{63} \mathrm{H}_{93} \mathrm{~N}_{11} \mathrm{O}_{22}\right):$ 1,355.7; found: $m / z=1,356.2[\mathrm{M}+\mathrm{H}]^{+}, 1,378.2[\mathrm{M}+\mathrm{Na}]^{+}, 679.2$ $[\mathrm{M}+2 \mathrm{H}]^{2+}$.

\section{Synthesis of the radioiodination precursor (13)}

The synthesis was performed according to previously published methods [12,31,32].

Succinimidyl-4-iodobenzoate (I-BA-NHS, 14): Under a nitrogen atmosphere, $500 \mathrm{mg}(2.0 \mathrm{mmol}, 1.0 \mathrm{eq})$ 4iodobenzoic acid was dissolved in $10 \mathrm{~mL} \mathrm{DCM}$, and after addition of $278 \mathrm{mg}$ (2.4 mmol, $1.2 \mathrm{eq}) N$-hydroxysuccinimide and $374 \mathrm{mg}$ (1.81 mmol, $0.9 \mathrm{eq})$ dicyclohexyl carbodiimide, the suspension was stirred overnight. The precipitate was filtered off, and the filtrate was evaporated to dryness. The resulting solid was washed with a 1:1-mixture of DCM and hexane to yield the desired product (583.5 mg, 93\%) as a white solid. Due to the limited detectability of the product in ESI-mass spectrometry (MS), a representative conjugate with $\mathrm{H}$-Phe-OtBu (1 eq) was prepared in DMF in the presence of DIPEA (3 eq) and characterized via MS. HPLC (40\% to $100 \%$ B in $15 \mathrm{~min}$ ): $t_{R}=10.6 \mathrm{~min} ; K^{\prime}=5.63$. Calculated monoisotopic mass for I-BA-Phe $(\mathrm{OtBu})\left(\mathrm{C}_{20} \mathrm{H}_{22} \mathrm{INO}_{3}\right)$ : 451.1; found: $m / z=396.1$ $[\mathrm{M}+\mathrm{H}-\mathrm{tBu}]^{+}$.

Succinimidyl-4-tributylstannyl-benzoate $\left(\mathrm{SnBu}_{3}-\mathrm{BA}-\right.$ NHS, 15): To a solution of $100 \mathrm{mg}(0.29 \mathrm{mmol}, 1.0 \mathrm{eq})$ 14 in $5 \mathrm{~mL}$ anhydrous toluene were added $234 \mu \mathrm{L}$ (0.464 mmol, $1.6 \mathrm{eq})$ of hexabutylditin and $10.7 \mathrm{mg}$ (9 $\mu \mathrm{mol}, 0.02 \mathrm{eq}$ ) of the catalyst tetrakis(triphenylphosphine)palladium under a nitrogen atmosphere. The mixture was heated under reflux until the solution turned black (overnight). After cooling, the toluene was removed in vacuo, and the resulting oil was purified using silica gel flash chromatography (ethyl acetate/hexane: $3 / 7(\mathrm{v} / \mathrm{v})$ ) to yield 15 (78 $\mathrm{mg}, 53 \%$ ) as a colourless oil. TLC (ethyl acetate/hexane: $3 / 7): R_{f}=0.46$

$\left(\mathrm{SnBu}_{3}-\mathrm{BA}\right)(\mathrm{OtBu}) \mathrm{KuE}(\mathrm{OtBu})_{2}$ (13): To a solution of $19.0 \mathrm{mg}$ (0.039 mmol, $1.0 \mathrm{eq}) 3$ in $2 \mathrm{~mL}$ DCM were added $26.3 \mu \mathrm{L}(0.187 \mathrm{mmol}, 4.8 \mathrm{eq})$ of TEA and $19.8 \mathrm{mg}$ $(0.039 \mathrm{mmol}, 1.0 \mathrm{eq})$ of $\mathbf{1 5}$. The mixture was stirred at RT for $4 \mathrm{~h}$ and was then diluted with DCM. After washing with water, the organic phase was dried over $\mathrm{Na}_{2} \mathrm{SO}_{4}$, filtered and evaporated to dryness. 13 (30.8 mg, $89.7 \%$ ) was obtained as a colourless oil. HPLC (10\% to
90\% B in $15 \mathrm{~min}$ ): $t_{R}=23.8 \mathrm{~min} ; K^{\prime}=13.88$. Calculated monoisotopic mass for $13\left(\mathrm{C}_{43} \mathrm{H}_{75} \mathrm{~N}_{3} \mathrm{O}_{8} \mathrm{Sn}\right)$ : 880.8; found: $m / z=902.2 / 903.3 / 904.3[\mathrm{M}+\mathrm{Na}]^{+}$.

\section{Synthesis of unlabelled reference compounds}

(I-BA)KuE: To a solution of $15 \mathrm{mg}(0.031 \mathrm{mmol}$, 1.0 eq) 3 in $2 \mathrm{~mL}$ DMF was added $11.4 \mathrm{mg}$ (0.046 mmol, $1.5 \mathrm{eq})$ of 4-iodo-benzoic acid, $6.3 \mathrm{mg}$ (0.046 mmol, $1.5 \mathrm{eq}$ ) of 1-Hydroxy-7-azabenzotriazole (HOAt), $7.2 \mu \mathrm{L}(0.046 \mathrm{mmol}, 1.5 \mathrm{eq})$ diisopropyl carbodiimide (DIC) and $23.7 \mu \mathrm{L}(0.138 \mathrm{mmol}, 4.5 \mathrm{eq})$ DIPEA. The yellow solution was stirred for $20 \mathrm{~h}$, diluted with ethyl acetate and extracted with water. The organic layer was dried over $\mathrm{Na}_{2} \mathrm{SO}_{4}$, filtered and evaporated to dryness. For $t \mathrm{Bu}$-deprotection, the crude product was dissolved in $200 \mu \mathrm{L}$ TFA. After $30 \mathrm{~min}$, the solvent was evaporated and the crude product was purified using preparative RP-HPLC (isocratic eluent: $18 \% \mathrm{~B})$. HPLC $(10 \%$ to $90 \% \mathrm{~B}$ in $15 \mathrm{~min}): t_{R}=$ $10.5 \mathrm{~min} ; K^{\prime}=5.56$ calculated monoisotopic mass for (I-BA) KuE $\left(\mathrm{C}_{19} \mathrm{H}_{24} \mathrm{IN}_{3} \mathrm{O}_{8}\right): 549.3$; found: $m / z=550.0$ $[\mathrm{M}+\mathrm{H}]^{+}, 571.9[\mathrm{M}+\mathrm{Na}]^{+}$

${ }^{n a t} \mathrm{Ga}$ compounds: For the preparation of the ${ }^{\text {nat }} \mathrm{Ga}$ complexes, equal volumes of a $2 \mathrm{mM}$ solution of $\mathrm{Ga}$ $\left(\mathrm{NO}_{3}\right)_{3}$ in water and a $2 \mathrm{mM}$ solution of the respective PSMA ligand in water were mixed and heated to $40^{\circ} \mathrm{C}$ for $30 \mathrm{~min}$. After cooling, the ${ }^{\text {nat }} \mathrm{Ga}^{\mathrm{III}}$-chelate formation was confirmed using RP-HPLC and MS. The resulting $1 \mathrm{mM}$ aqueous solutions of the respective ${ }^{\text {nat }} \mathrm{Ga}$-complexes were then further diluted and used in the in vitro $\mathrm{IC}_{50}$ studies without further processing.

$\left[{ }^{\text {nat }} \mathrm{Ga}\right.$ ]DOTA-FFK(Sub-KuE) ( $\left.{ }^{\text {nat }} \mathrm{Ga-10}\right)$ HPLC $(20 \%$ to $60 \% \mathrm{~B}$ in $15 \mathrm{~min}): t_{R}=11.6 \mathrm{~min} ; K^{\prime}=6.3$. Ccalculated monoisotopic mass $\left(\mathrm{C}_{60} \mathrm{H}_{86} \mathrm{~N}_{11} \mathrm{O}_{20} \mathrm{Ga}\right)$ : 1,349.5; found: $m / z=1,350.3[\mathrm{M}+\mathrm{H}]^{+}, 1,372.1[\mathrm{M}+\mathrm{Na}]^{+}$, $675.7[\mathrm{M}+2 \mathrm{H}]^{2+}$.

$\left[{ }^{\text {nat }} \mathrm{Ga}\right.$ ]DOTAGA-FFK(Sub-KuE) $\left({ }^{\text {nat }} \mathrm{Ga-11}\right) \mathrm{HPLC}(25 \%$ to $45 \% \mathrm{~B}$ in $15 \mathrm{~min}$ ): $t_{R}=16.0 \mathrm{~min} ; K^{\prime}=9.0$. Calculated monoisotopic mass $\left(\mathrm{C}_{63} \mathrm{H}_{90} \mathrm{~N}_{11} \mathrm{O}_{22} \mathrm{Ga}\right)$ : 1,421.7, 1,423.7; found: $m / z=1,422.1 / 1,424.1[\mathrm{M}+\mathrm{H}]^{+}, 710.6 / 712.6$ $[\mathrm{M}+2 \mathrm{H}]^{2+}$.

$\left[{ }^{\text {nat }} \mathrm{Ga}\right]$ DOTAGA-ffk(Sub-KuE) $\left({ }^{\text {nat }} \mathrm{Ga}-12\right)$ HPLC (25\% to $55 \% \mathrm{~B}$ in $15 \mathrm{~min}): t_{R}=12.1 \mathrm{~min} ; K^{\prime}=7.6$. Calculated monoisotopic mass $\left(\mathrm{C}_{63} \mathrm{H}_{90} \mathrm{~N}_{11} \mathrm{O}_{22} \mathrm{Ga}\right)$ : 1,421.7, 1,423.7; found: $m / z=1,422.6 / 1,424.5[\mathrm{M}+\mathrm{H}]^{+}, 1,444.4 / 1,446.4$ $[\mathrm{M}+\mathrm{Na}]^{+}$.

[ ${ }^{\text {nat }} \mathrm{Ga}$ ]HBED-CC-Ahx-KuE HPLC (25\% to $43 \% \mathrm{~B}$ in $15 \mathrm{~min}): t_{R}=9.0 \mathrm{~min} ; K^{\prime}=5.0$. Calculated monoisotopic mass $\left(\mathrm{C}_{44} \mathrm{H}_{59} \mathrm{~N}_{6} \mathrm{O}_{17} \mathrm{Ga}\right): 1,012.3,1,014.3$; found: $m / z=$ 1,013.0/1,015.0 $[\mathrm{M}+\mathrm{H}]^{+}, 1,035.0 / 1,037.0[\mathrm{M}+\mathrm{Na}]^{+}$.

${ }^{n a t} L u$-compounds: The corresponding ${ }^{\text {nat }} \mathrm{Lu}^{\mathrm{III}}$ complexes were prepared with a 2.5-molar excess of $\mathrm{Lu}^{3+}$, heated at $95^{\circ} \mathrm{C}$ for $30 \mathrm{~min}$ and evaluated similar to the ${ }^{\text {nat }} \mathrm{Ga}^{\mathrm{III}}$ complexes. 
[ ${ }^{\text {nat }}$ Lu]DOTA-FFK(Sub-KuE) $\left({ }^{\text {nat }} \mathrm{Lu}-10\right)$ HPLC (25\% to $45 \% \mathrm{~B}$ in $16 \mathrm{~min}$ ): $t_{R}=14.1 \mathrm{~min} ; K^{\prime}=9.1$. Calculated monoisotopic mass $\left(\mathrm{C}_{60} \mathrm{H}_{86} \mathrm{~N}_{11} \mathrm{O}_{20} \mathrm{Lu}\right): 1$, 455.6 ; found: $m / z=1,456.4[\mathrm{M}+\mathrm{H}]^{+}, 1,478.5[\mathrm{M}+\mathrm{Na}]^{+}$.

$\left[{ }^{\text {nat }}\right.$ Lu]DOTAGA-FFK(Sub-KuE) $\quad\left({ }^{\text {nat }} \mathrm{Lu}-11\right) \quad$ HPLC ( $25 \%$ to $45 \% \mathrm{~B}$ in $16 \mathrm{~min}$ ): $t_{R}=14.4 \mathrm{~min} ; K^{\prime}=9.3$. Calculated monoisotopic mass $\left(\mathrm{C}_{63} \mathrm{H}_{90} \mathrm{~N}_{11} \mathrm{O}_{22} \mathrm{Lu}\right)$ : 1,527.6; found: $m / z=1,528.4[\mathrm{M}+\mathrm{H}]^{+}, 1,550.3[\mathrm{M}+\mathrm{Na}]^{+}, 764.2$ $[\mathrm{M}+2 \mathrm{H}]^{2+}$.

$\left[{ }^{\text {nat }} \mathrm{Lu}\right]$ DOTAGA-ffk(Sub-KuE) $\left({ }^{\text {nat }} \mathrm{Lu}-12\right)$ HPLC $(25 \%$ to $55 \% \mathrm{~B}$ in $15 \mathrm{~min}$ ): $t_{R}=10.4 \mathrm{~min} ; K^{\prime}=6.4$. Calculated monoisotopic mass $\left(\mathrm{C}_{63} \mathrm{H}_{90} \mathrm{~N}_{11} \mathrm{O}_{22} \mathrm{Lu}\right): 1$,527.6; found: $m / z=1,528.1[\mathrm{M}+\mathrm{H}]^{+}, 764.5[\mathrm{M}+2 \mathrm{H}]^{2+}$.

\section{Radiolabelling}

$\left(\left[{ }^{125} I\right] I-B A\right) K u E$ : The radioiodination was performed according to previously published methods [12,31,32]. Peracetic acid was prepared by mixing $130 \mu \mathrm{L}$ of $\mathrm{H}_{2} \mathrm{O}_{2}$ (30\%) and $50 \mu \mathrm{L}$ of acetic acid. After a 2 h-incubation period, $20 \mu \mathrm{L}$ peracetic acid solution and $5 \mu \mathrm{L}(21.0 \mathrm{MBq})$ $\left[{ }^{125} \mathrm{I}\right] \mathrm{NaI}(74 \mathrm{TBq} / \mathrm{mmol}, 3.1 \mathrm{GBq} / \mathrm{mL} 40 \mathrm{mM} \mathrm{NaOH}$, Hartmann Analytic, Braunschweig, Germany) was added to a solution of approximately $0.1 \mathrm{mg} \mathbf{1 5}$ in $20 \mu \mathrm{L} \mathrm{MeCN/}$ acetic acid (1/1) and incubated at RT for $10 \mathrm{~min}$. The product was diluted with $10 \mathrm{~mL}$ of water and loaded onto a C18 Sep Pak Plus cartridge, which had been preconditioned with $10 \mathrm{~mL}$ of $\mathrm{MeOH}$ and rinsed with $10 \mathrm{~mL}$ of water. The cartridge was then washed with $10 \mathrm{~mL}$ water, and the product was eluted in 300 to $500 \mu \mathrm{L}$ fractions with a 1:1 mix $(\mathrm{v} / \mathrm{v})$ of $\mathrm{EtOH} / \mathrm{MeCN}(2 \mathrm{~mL})$. The radioactive fractions were evaporated to dryness, and the residue was dissolved in $200 \mu \mathrm{L}$ TFA. After $30 \mathrm{~min}$, the solvent was evaporated in vacuo. The crude product was isolated from unlabelled tributyltin precursor by RP-HPLC ( $20 \%$ to $40 \%$ $B$ in $20 \mathrm{~min})$ to afford the desired product $(10.9 \mathrm{MBq})$. $\operatorname{HPLC}(20 \%$ to $40 \% \mathrm{~B}, 220 \mathrm{~nm}): t_{R}=13.0 \mathrm{~min}, K^{\prime}=6.22$.

${ }^{68}$ Ga-labelling: A $1.25 \mathrm{~mL}$ fraction of ${ }^{68} \mathrm{Ge} /{ }^{68} \mathrm{Ga}$ generator (iTHEMBA Labs, South Africa) eluate $(1 \mathrm{M} \mathrm{HCl})$ was loaded onto a self-filled cartridge containing $300 \mathrm{mg}$ SCX material (Bond Elut-SCX, Varian). The cartridge was then washed with water $(1.0 \mathrm{~mL})$ and purged with air. The ${ }^{68} \mathrm{Ga}^{3+}$ was eluted with aq. $\mathrm{NaCl}(5 \mathrm{M}, 0.5 \mathrm{~mL})$ and HEPES ( $2.7 \mathrm{M}$ aq., 90 or $140 \mu \mathrm{L}$ ) was added (pH 3.5 or 4.5 , respectively). That solution was mixed with the precursor $(3 \mathrm{nmol}$ in $10 \mu \mathrm{L})$ and heated at $95^{\circ} \mathrm{C}$ for $5 \mathrm{~min}$. After cooling, labelling efficiency and radiochemical purity were determined using Radio-TLC and Radio-HPLC. Radiochemical purity of all ${ }^{68} \mathrm{Ga}$-labelled conjugates was $\geq 95 \%$. Therefore, the tracers were diluted and used in vitro experiments without further purification. Tracers for in vivo use were prepared in GMPcompliant procedure using a fully automated synthesis module (Scintomics GmbH, Germany) similar to the procedure described previously [33]. For animal studies, the EtOH for eluting the labelled tracer from a SPE cartridge was evaporated in vacuo.

${ }^{177}$ Lu-labelling: A $0.1 \mathrm{mM}$ aqueous solution of chelatorcoupled peptide $(0.66 \mathrm{nmol})$ was added to $25 \mathrm{MBq}\left[{ }^{177} \mathrm{Lu}\right]$ $\mathrm{LuCl}_{3}(170 \mathrm{GBq} / \mu \mathrm{mol}, 17 \mathrm{GBq} / \mathrm{mL} 0.05 \mathrm{M} \mathrm{HCl}$, IDB Radiopharmacy bv). The $\mathrm{pH}$ was adjusted to $\mathrm{pH} 5$ by the addition of approximately $150 \mu \mathrm{L} 0.1 \mathrm{M} \mathrm{NH}_{4} \mathrm{OAc}$ solution. After $45 \mathrm{~min}$ at $95^{\circ} \mathrm{C}$, the labelling efficiency was examined by TLC and RP-HPLC.

\section{Determination of lipophilicity}

To a solution of 0.5 to $1 \mathrm{MBq}$ of radiolabelled peptide in $500 \mu \mathrm{l}$ of phosphate-buffered saline (PBS, $\mathrm{pH}$ 7.4), $500 \mu \mathrm{l}$ of $\mathrm{n}$-octanol was added $(n=6)$. Vials were vortexed vigorously for $3 \mathrm{~min}$. To achieve quantitative phase separation, the vials were centrifuged at $6,000 \mathrm{~g}$ for $5 \mathrm{~min}$ in a Biofuge 15 (Heraeus Sepatech, Osterode, Germany). The activity concentrations in $100 \mu$ l-samples of both the aqueous and the organic phase were measured in a $\gamma$-counter. Both the partition coefficient $P_{(\mathrm{o} /}$ $\left.{ }_{w}\right)$, which is defined as the molar concentration ratio of a single species A between n-octanol and water at equilibrium, and $\log P_{(\mathrm{o} / \mathrm{w})}$, which is an important parameter used to characterize lipophilicity of a compound, were calculated.

\section{Metabolite analysis}

${ }^{177} \mathrm{Lu}-10$ and ${ }^{177} \mathrm{Lu}-\mathbf{1 1}$ were incubated in $80 \mu \mathrm{L}$ of human serum $\left(37^{\circ} \mathrm{C}\right)$ and $80 \mu \mathrm{L}$ 0.4 M DTPA solution (RT), respectively and after 1,24 and $48 \mathrm{~h}$, the stability was determined by TLC analysis. The ${ }^{68} \mathrm{Ga}$-labelled tracers (40 to $45 \mathrm{MBq}$ ) were injected into the tail vein of CD-1 nu/nu mice. The animals were sacrificed after $30 \mathrm{~min}$, and urine, blood and kidney samples were taken. The kidney was frozen in liquid nitrogen, homogenized with a ball mill and extracted with 0.2 to $1 \mathrm{~mL}$ PBS containing $200 \mathrm{nmol}$ 2-(phosphonomethyl)pentane-1,5-dioic acid (PMPA). The suspension was first centrifuged $(15,000 \mathrm{~g})$, and after ultrafiltration, the extracts were analysed by RP-HPLC. The blood samples were centrifuged to separate the plasma from the blood cells. Plasma proteins were removed by precipitation with acetonitrile $\left(10 \mathrm{~min}, 4^{\circ} \mathrm{C}\right)$ and subsequent centrifugation and ultrafiltration. The blood extract was also analysed by RP-HPLC.

\section{In vitro assays}

Cell culture: PSMA $^{+}$LNCaP cells (CLS: 300265) were grown in DMEM/Nutrition Mix F-12 with Glutamax-I (1:1) (Invitrogen, Life Technologies, Darmstadt, Germany) supplemented with $10 \%$ FCS. Cultures were maintained at $37^{\circ} \mathrm{C}$ in a $5 \% \mathrm{CO}_{2} /$ humidified air atmosphere. One day prior to the experiment, cells were harvested using Tryp$\sin /$ EDTA $(0.05 \%$ and $0.02 \%)$ in PBS, centrifuged and 
resuspended with culture medium. For cell counting, a Countesse automated cell counter (Invitrogen, Carlsbad, USA) was used. All in vitro binding and internalization studies were performed using live cells seeded 1 day prior to the experiment. For $\mathrm{IC}_{50}$ determination, 150,000 cells/ $\mathrm{mL}$ were transferred to 24 -well plates $(1 \mathrm{~mL} /$ well $)$, and for internalization studies, 125,000 cells/mL were transferred into PLL-coated 24-well plates.

Determination of $I C_{50}$ : The culture medium was removed, and the cells were washed once with $500 \mu \mathrm{L}$ of HBSS (Hank's balanced salt solution, Biochrom, Berlin, Germany, containing 1\% bovine serum albumin (BSA)), before being left to equilibrate in $200 \mu \mathrm{L}$ of HBSS (1\% BSA) on ice for $15 \mathrm{~min}$. Then, $25 \mu \mathrm{L} /$ well of either HBSS (1\% BSA; control) or of solutions containing the respective unlabelled ligand of interest in increasing concentrations $\left(10^{-10}-10^{-4} \mathrm{M}\right.$ in HBSS (1\% BSA)) was added, followed by the addition of $25 \mu \mathrm{L}$ of $\left(\left[{ }^{125} \mathrm{I}\right] \mathrm{I}-\mathrm{BA}\right) \mathrm{KuE}$ in HBSS (1\% BSA). Experiments were carried out in triplicate for each concentration. The final radioligand concentration was $0.2 \mathrm{nM}$ in all binding assays. Cells were incubated on ice for $60 \mathrm{~min}$. Incubation was terminated by the removal of the incubation medium. Cells were thoroughly rinsed with $250 \mu \mathrm{L}$ of HBSS. The wash medium was combined with the supernatant of the previous step. This fraction represents the amount of free radioligand. Cells were then lysed using $250 \mu \mathrm{L}$ of $1 \mathrm{~N}$ $\mathrm{NaOH}$, the lysate was transferred to vials and combined with $250 \mu \mathrm{L}$ of HBSS used for rinsing the wells. Quantification of the amount of free and bound activity was performed in a $\gamma$-counter.

Internalization studies: The culture medium was removed, and the cells were washed once with $500 \mu \mathrm{L}$ DMEM-F12 (5\% BSA) before being left to equilibrate in $200 \mu \mathrm{L}$ DMEM-F12 (5\% BSA) at $37^{\circ} \mathrm{C}$ for a minimum of $15 \mathrm{~min}$. Then, $25 \mu \mathrm{L}$ (per well) of either DMEM-F12 (5\% $\mathrm{BSA}$ ) or of a 100- $\mu \mathrm{M}$ PMPA solution (blocking) was added, followed by the addition of $25 \mu \mathrm{L}$ of ${ }^{68} \mathrm{Ga} /{ }^{177} \mathrm{Lu}$ labelled PSMA ligand. The final radioligand concentration was $0.2 / 0.5 \mathrm{nM}$ in all internalization assays. To determine internalization kinetics, cells were then incubated at $37^{\circ} \mathrm{C}$ for $5,15,30$ and $60 \mathrm{~min}$, respectively. Experiments were carried out in triplicate for each time point (control and blocking). Incubation was terminated by placing the plate on ice for approximately $1 \mathrm{~min}$ and by subsequent removal of the incubation medium. Cells were thoroughly rinsed with $250 \mu \mathrm{L}$ of PBS. The wash medium was combined with the supernatant of the previous step. This fraction represents the amount of free radioligand. To remove receptor surface bound radioactivity, the cells were then incubated for $10 \mathrm{~min}$ with $250 \mu \mathrm{L}$ of ice cold PMPA solution (10 $\mu \mathrm{M}$ in PBS). After removal of the supernatant, the cells were thoroughly rinsed with another $250 \mu \mathrm{L}$ of ice cold PBS. Both fractions were combined. The internalized activity was released by incubation with $250 \mu \mathrm{L}$ of $1 \mathrm{~N} \mathrm{NaOH}$, transferred to vials and combined with $250 \mu \mathrm{L}$ of $1 \mathrm{~N} \mathrm{NaOH}$ used for rinsing the wells. Quantification of the amount of free, PMPA-releasable and internalized activity was performed in a $\gamma$-counter.

\section{In vivo experiments}

All animal experiments were conducted in accordance with general animal welfare regulations in Germany (Deutsches Tierschutzgesetz, approval \#55.2-1-54-253271-13). The prostate cancer cell line LNCaP was suspended $1 / 1$ in serum-free medium and Matrigel (BD Biosciences, Germany) and approximately $10^{7}$ cells in $200 \mu \mathrm{L}$ were inoculated subcutaneously on the right shoulder of 6 to 8 weeks old CD-1 nu/nu mice (Charles River Laboratories). Tumours were grown for 2 to 4 weeks (males) and 4 to 6 weeks (females) to reach 4 to $8 \mathrm{~mm}$ in diameter.

Biodistribution: The ${ }^{68}$ Ga-labelled PSMA ligands (approximately 7 to $15 \mathrm{MBq}, 0.1$ to $0.2 \mathrm{nmol}$ ) were injected into the tail vein of isoflurane anesthetized animals. The organ distribution was examined $1 \mathrm{~h}$ p.i. and quantified in a $\gamma$-counter.

$\mu P E T$ imaging: Imaging studies were performed at a Siemens Inveon small animal PET, followed by data analysis using the Inveon Research Workplace software. The animals were anesthesized with isoflurane and injected via tail vein with 14 to $18 \mathrm{MBq}(0.2 \mathrm{nmol})$ of tracer. Dynamic imaging was performed after on-bed injection for $1.5 \mathrm{~h}$. Static images were recorded at $1 \mathrm{~h}$ p.i. with an acquisition time of $15 \mathrm{~min}$. For the blockade image, animals were coinjected with $8 \mathrm{mg} / \mathrm{kg}$ of PMPA. Images were reconstructed using $3 \mathrm{D}$ ordered-subsets expectation maximum (OSEM3D) algorithm without scanner and attenuation correction.

\section{Results}

\section{Chemistry}

The $t \mathrm{Bu}$-protected PSMA binding motif $((\mathrm{OtBu}) \mathrm{KuE}$ $\left.(\mathrm{OtBu})_{2}, 3\right)$ was synthesized in $73 \%$ yield via three steps of solution phase chemistry as previously described with minor modifications (Figure 3, [12]).

The ligands DOTA-FFK(Sub-KuE) (10), DOTAGAFFK(Sub-KuE) (11) and DOTAGA-ffk(Sub-KuE) (12) were prepared according to Figure 4 . The peptidic spacers H-L-Phe-L-Phe-L-Lys(Boc)-OH (FFK(Boc), 5) and H-D-Phe-D-Phe-D-Lys(Boc)-OH (ffk(Boc), 6) were synthesized via solid phase peptide synthesis using a standard Fmoc protocol. The prochelators DOTA-tris- $t \mathrm{Bu}$-ester and DOTAGA-anhydride were coupled to the resinbound peptides in almost quantitative yields. Subsequently, the chelator-conjugated peptides were cleaved from the resin (TFA/TIBS/ $\mathrm{H}_{2} \mathrm{O}$ ) and simultaneously 


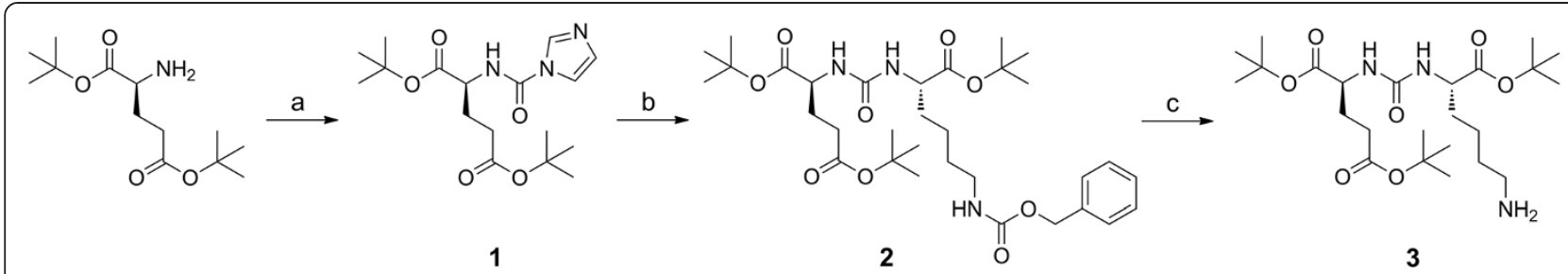

Figure 3 Synthesis of the PSMA binding motif 3. (a) DCl, TEA, DMAP [DCM]; (b) H-Lys(Z)-OtBu, TEA [DCE]; (c) Pd/C (10\%), H2 [EtOH].

deprotected to yield $7, \mathbf{8}$ and $\mathbf{9}$. The $t$ Bu-protected PSMA binding motif 3 was first reacted with DSS in solution and then coupled with the chelatorfunctionalized peptides 7, 8 and 9. After acidic cleavage of the remaining $t \mathrm{Bu}$-protecting groups, the final products were purified by RP-HPLC. The products were obtained in approximately $15 \%$ yield (based on tripeptide). The identity of $\mathbf{1 0}, \mathbf{1 1}$ and $\mathbf{1 2}$ was confirmed by MS.

The ${ }^{\text {nat }} \mathrm{Ga}^{\mathrm{III}}$ and ${ }^{\text {nat }} \mathrm{Lu}^{\mathrm{III}}$ complexes of compounds $\mathbf{1 0}$, 11 and 12 were prepared by incubation of 10,11 and 12 with an equimolar amount of aq. $\mathrm{Ga}\left(\mathrm{NO}_{3}\right)_{3}$ at $40^{\circ} \mathrm{C}$ for $30 \mathrm{~min}$ and an 2.5 -molar excess of $\mathrm{LuCl}_{3}$ at $95^{\circ} \mathrm{C}$ for $30 \mathrm{~min}$, respectively. Quantitative metal complex formation was confirmed by RP-HPLC and MS.

\section{Radiochemistry}

$\left(\left[{ }^{125} \mathrm{I}\right] \mathrm{I}-\mathrm{BA}\right) \mathrm{KuE}$, the reference radioligand in all PSMA binding assays carried out in this study, was synthesized in solution starting from 4-iodo-benzoic acid according to methods described in the literature $[12,31,32]$. The respective $\mathrm{Bu}_{3} \mathrm{Sn}$-precursor $\mathbf{1 3}$ was destannylated with $\left[{ }^{125} \mathrm{I}\right] \mathrm{NaI}$ using peracetic acid as the oxidizing agent within $10 \mathrm{~min}$ at RT. After cartridge purification subsequent $t \mathrm{Bu}$-deprotection and RP-HPLC purification, the final product was obtained in a radiochemical yield of $44 \pm 5 \%$ and radiochemical purity of $>99 \%$. The reference material for chromatographic analyses (cold) (I-BA)KuE was synthesized by coupling 4-iodo-benzoic acid to $\mathbf{3}$, subsequent $t \mathrm{Bu}$-deprotection and RP-HPLC purification.

Preparation of ${ }^{68} \mathrm{Ga}$ for labelling of 10,11 and 12 was performed by combination of previously described methods $[34,35]$ with minor modifications. The ${ }^{68} \mathrm{Ga}^{3+}$ eluted with $1 \mathrm{M} \mathrm{HCl}$ from a ${ }^{68} \mathrm{Ge} /{ }^{68} \mathrm{Ga}$ generator (iThemba Labs, South Africa) was retained on a strong cation exchange cartridge followed by elution with $0.5 \mathrm{~mL} 5 \mathrm{M} \mathrm{NaCl}$, resulting in highly concentrated ${ }^{68} \mathrm{Ga}$ activity. Quantitative ${ }^{68} \mathrm{Ga}$-complexation was achieved using $3 \mathrm{nmol}$ of the respective DOTA- or DOTAGAconjugated PSMA inhibitors $\left(95^{\circ} \mathrm{C}, 5 \mathrm{~min}, \mathrm{pH}\right.$ adjusted to 3.5 and 4.5 by addition of $2.7 \mathrm{M}$ HEPES, respectively), allowing their use in in vitro studies without further purification. Specific activities of the ${ }^{68} \mathrm{Ga}$-labelled PSMA inhibitors were 250 to $300 \mathrm{GBq} / \mu \mathrm{mol}$. The ${ }^{68} \mathrm{Ga}$-labelling for in vivo biodistribution and PET imaging studies were carried out using a fully automated GMP-compliant procedure using a GRP synthesizer (Scintomics GmbH, Germany) [33]. In these cases, the obtained specific activities were 80 to $120 \mathrm{GBq} / \mu \mathrm{mol}$.

To obtain RCY $>95 \%$ for complexation of 10, 11 and 12 with $\left[{ }^{177} \mathrm{Lu}\right] \mathrm{LuCl}_{3}, 0.66 \mathrm{nmol}$ of precursor were reacted with $25 \mathrm{MBq}\left[{ }^{177} \mathrm{Lu}\right] \mathrm{LuCl}_{3}\left(A_{\mathrm{S}}=170 \mathrm{GBq} / \mu \mathrm{mol}\right)$ at pH $5\left(0.1 \mathrm{M} \mathrm{NH}_{4} \mathrm{OAc}, 95^{\circ} \mathrm{C}, 45 \mathrm{~min}\right)$ resulting in specific activities of $A_{\mathrm{S}} \geq 38 \mathrm{GBq} / \mu \mathrm{mol}$.

\section{PSMA binding affinity}

The PSMA binding affinities were determined in a competitive binding assay using LNCaP human prostate carcinoma cells and the known high affinity PSMA ligand $\left(\left[{ }^{125} \mathrm{I}\right] \mathrm{I}-\mathrm{BA}\right) \mathrm{KuE}[10](c=0.2 \mathrm{nM})$ as the radioligand. The $\mathrm{IC}_{50}$ values for the metal-free PSMA-inhibiting compounds and their respective ${ }^{\text {nat }} \mathrm{Ga}$ and ${ }^{\text {nat }} \mathrm{Lu}$ complexes are summarized in Table 1. HBED-CC-Ahx-KuE and $\left[{ }^{\text {nat }} \mathrm{Ga}\right]$ HBED-CC-Ahx-KuE [12] were included in this study as reference compounds. The PSMA affinities of 11 and 12, as well as their respective ${ }^{\text {nat }} \mathrm{Ga}$ and ${ }^{\text {nat }} \mathrm{Lu}$ analogues were consistently higher than the affinities of the respective DOTA constructs (10). Substitution of the L-amino acids in the linker region of the ligands by D-amino acids showed only a negligible effect on PSMA affinity (12 vs 11).

\section{Internalization kinetics and specificity of cell binding}

The cellular uptake and internalization kinetics of the different ${ }^{68} \mathrm{Ga}$ - and ${ }^{177} \mathrm{Lu}$-labelled PSMA ligands was determined using PSMA-expressing LNCaP cells. In the case of the ${ }^{68} \mathrm{Ga}$-labelled compounds, the final peptide concentration in the assays was $0.2 \mathrm{nM}$. Since all ${ }^{177} \mathrm{Lu}$ analogues were obtained in significantly lower specific activities than the ${ }^{68} \mathrm{Ga}$ analogues, the ligand concentration had to be increased to $0.5 \mathrm{nM}$ to obtain reasonable count rates for assay evaluation. All internalization studies were accompanied by reference studies using $\left(\left[{ }^{125} \mathrm{I}\right] \mathrm{I}-\mathrm{BA}\right) \mathrm{KuE}(c=0.2 \mathrm{nM})$. This experimental setup allows data normalization and eliminates the influence of cell count and cell viability on absolute cellular tracer uptake. To investigate the specificity of binding to PSMA, experiments were also carried out in the presence 


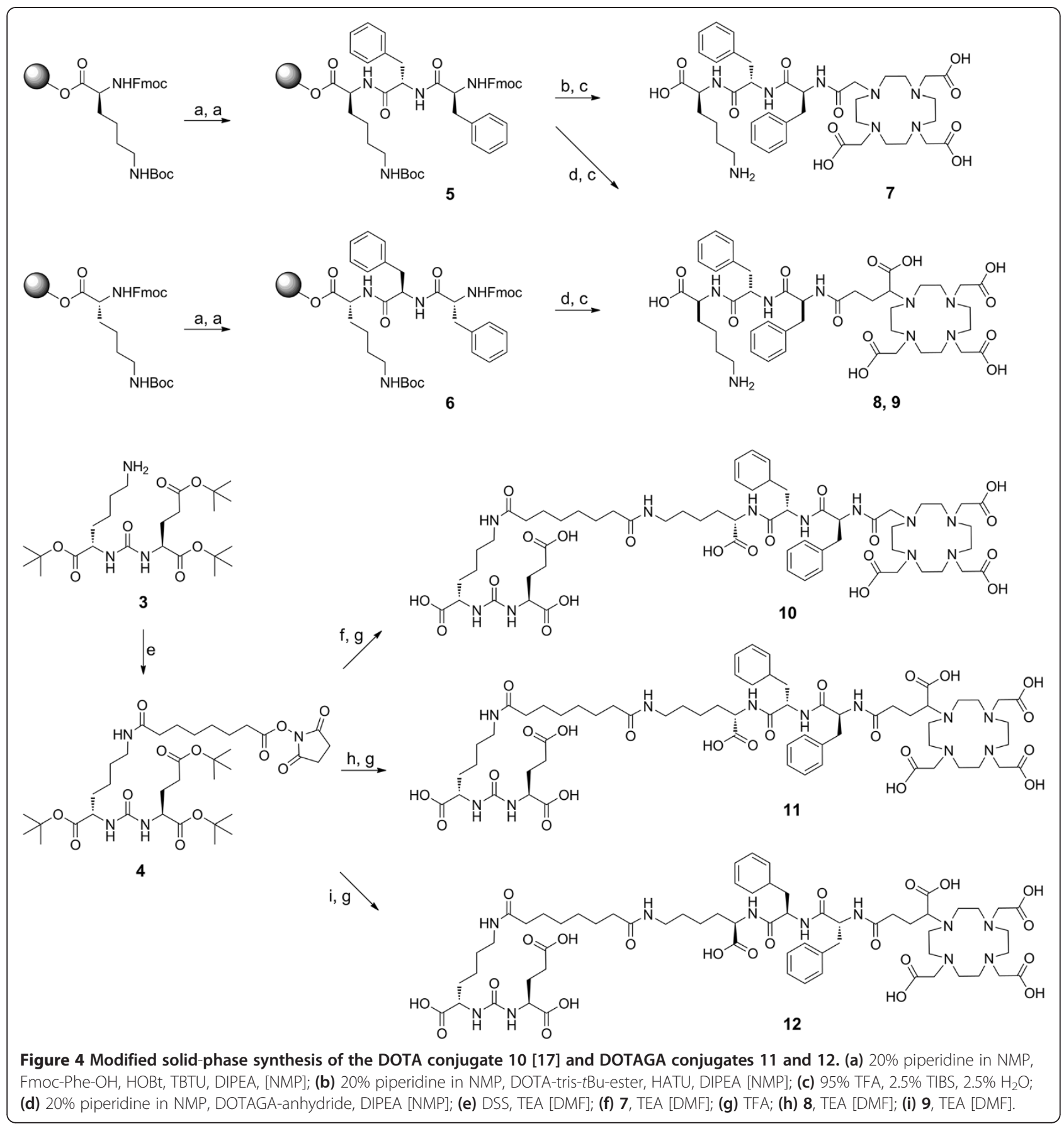

of $10 \mu \mathrm{M}$ PMPA, a known high-affinity PSMA inhibitor (1.4 nM, [7]). Furthermore, to be able to discriminate between total cellular activity (sum of membrane associated and internalized activity) and internalized activity, all incubations were followed by a washing step with $10 \mu \mathrm{M}$ PMPA at $4^{\circ} \mathrm{C}$ to remove specifically cell-surface bound radioligand by displacement.

Non-specific binding in the presence of $10 \mu \mathrm{M}$ PMPA was lower than $0.5 \%$ for all compounds investigated. As expected, the cellular binding and internalization of all radiometalated PSMA ligands in this study increased over the time of observation $(1 \mathrm{~h})$. For all compounds, the fraction of internalized activity ranged between $4.5 \pm$ $0.2 \%$ and $27.7 \pm 1.6 \%$ of the total added activity after $1 \mathrm{~h}$. The fraction of non-internalized, i.e. membrane-bound activity was $1 \%$ to $3 \%$ in all experiments (exemplarily shown for ${ }^{177} \mathrm{Lu}-10$ and ${ }^{177} \mathrm{Lu}-11$ in Figure 5).

Variations in cell count and/or cell viability between experiments can significantly affect the cellular tracer uptake but cannot be fully avoided. Therefore, 
Table 1 PSMA affinities $\left(\mathrm{IC}_{50}\right)$ of the compounds investigated

\begin{tabular}{|c|c|c|}
\hline Ligand & & $\mathrm{IC}_{50}[\mathrm{nM}]$ \\
\hline HBED-CC-Ahx-KuE & & $5.7 \pm 0.5$ \\
\hline$\left[{ }^{\text {nat }}\right.$ Ga]HBED-CC-Ahx-KuE & & $6.1 \pm 0.8$ \\
\hline DOTA-FFK(Sub-KuE) & (10) & $13.1 \pm 2.3$ \\
\hline [natGa]DOTA-FFK(Sub-KuE) & ( $\left.{ }^{\text {nat }} \mathrm{Ga}-10\right)$ & $29.5 \pm 6.6$ \\
\hline ["nat Lu]DOTA-FFK(Sub-KuE) & $\left({ }^{\text {nat }} L u-10\right)$ & $54.7 \pm 6.1$ \\
\hline DOTAGA-FFK(Sub-KuE) & $(\mathbf{1 1})$ & $10.2 \pm 1.5$ \\
\hline [nat Ga]DOTAGA-FFK(Sub-KuE) & ( $\left.{ }^{\text {nat }} \mathrm{Ga}-11\right)$ & $12.1 \pm 3.9$ \\
\hline$\left[{ }^{\text {nat Lu]DOTAGA-FFK(Sub-KuE) }}\right.$ & (natLu-11) & $15.1 \pm 1.5$ \\
\hline DOTAGA-ffk(Sub-KuE) & $(12)$ & $13.9 \pm 0.4$ \\
\hline [" ${ }^{\text {nat }}$ Ga]DOTAGA-ffk(Sub-KuE) & ( $\left.{ }^{\text {nat }} \mathrm{Ga}-12\right)$ & $15.9 \pm 0.5$ \\
\hline [natLu]DOTAGA-ffk(Sub-KuE) & $\left({ }^{\text {nat }} L u-12\right)$ & $13.1 \pm 2.2$ \\
\hline
\end{tabular}

internalization data (Table 2) are normalized to the uptake of $\left(\left[{ }^{125} \mathrm{I}\right] \mathrm{I}-\mathrm{BA}\right) \mathrm{KuE}$, that was always assayed in parallel as an external reference. All DOTA and DOTAGAcoupled ligands showed a lower internalization efficiency compared to the radioiodinated reference compound, whereas $\left[{ }^{68} \mathrm{Ga}\right] \mathrm{HBED}-\mathrm{CC}-\mathrm{Ahx}-\mathrm{KuE}$ was internalized almost to the same degree as $\left(\left[{ }^{125} \mathrm{I}\right] \mathrm{I}-\mathrm{BA}\right) \mathrm{KuE}$.

\section{Determination of lipophilicity}

The partition coefficient $\log P$ between $\mathrm{n}$-octanol and PBS was determined for the compounds listed in Table 3 using the shake flask method. All compounds are highly hydrophilic, with the DOTAGA compounds being up to one order of magnitude more hydrophilic than the

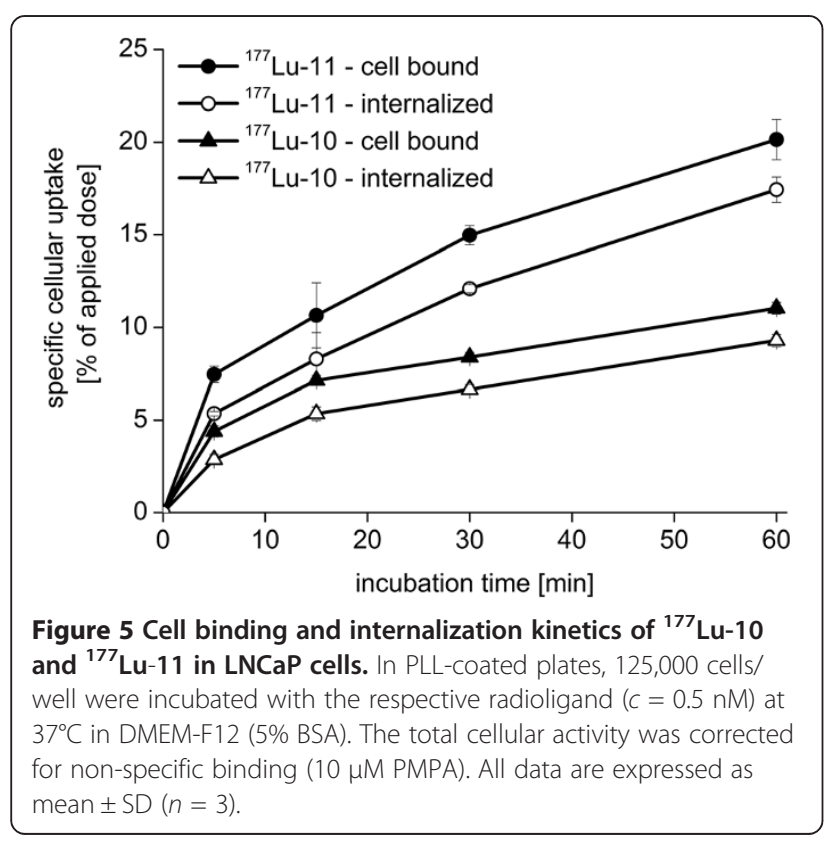

corresponding DOTA analogues. Amongst all compounds tested, $\left[{ }^{68} \mathrm{Ga}\right]$ HBED-CC-Ahx-KuE was the most hydrophilic compound.

\section{Metabolite analysis}

The stability of ${ }^{177} \mathrm{Lu}-\mathbf{1 0}$ and ${ }^{177} \mathrm{Lu}-\mathbf{1 1}$ was investigated by incubation in human serum for $48 \mathrm{~h}$ at $37^{\circ} \mathrm{C}$ and by DTPA challenge (0.4 M, RT, $48 \mathrm{~h}$ ) and subsequent TLC analysis. Release of ${ }^{177} \mathrm{Lu}^{\mathrm{III}}$ from the complexes was not observed under the respective experimental conditions in the examined time frame.

To investigate the influence of the amino acid composition of the spacer (KFF vs kff) on the metabolic stability in vivo, tissue homogenates and body fluids of mice injected with ${ }^{68} \mathrm{Ga}-11$ and ${ }^{68} \mathrm{Ga}-12$ were analysed by radio-HPLC. Representative HPLC profiles of extracts and body fluids are shown in Figure 6. Extraction efficiencies from the blood and from the kidney were $56 \%$ and $43 \%$ for ${ }^{68} \mathrm{Ga}-11$ and $61 \%$ and $62 \%$ for ${ }^{68} \mathrm{Ga}-12$, respectively. Rapid in vivo degradation was observed for ${ }^{68} \mathrm{Ga}-11$ consisting of the L-amino acid tripeptide FFK, resulting in only $21 \%$ intact tracer in blood at $0.5 \mathrm{~h}$. ${ }^{68} \mathrm{Ga}-12$ that consists of the D-amino acid tripeptide ffk, was found to be stable in blood (100\% intact tracer) at 0.5 h p.i..

\section{Biodistribution and small-animal PET studies}

A comparison of the biodistribution of compounds ${ }^{68} \mathrm{Ga}-11,{ }^{68} \mathrm{Ga}-12$ and the reference $\left[{ }^{68} \mathrm{Ga}\right]$ HBED-CCAhx-KuE in LNCaP-tumour-bearing CD-1 nu/nu mice $(1 \mathrm{~h}$ p.i.) is shown in Figure 7.

Comparative static PET scans were performed with ${ }^{68} \mathrm{Ga}-10,{ }^{68} \mathrm{Ga}-11,{ }^{68} \mathrm{Ga}-12$ and $\left[{ }^{68} \mathrm{Ga}\right]$ HBED-CC-Ahx$\mathrm{KuE}$ in the same animal model for $15 \mathrm{~min}$ at $1 \mathrm{~h}$ p.i.. The maximum intensity projections depicted in Figure 8 confirm higher tumour-to-background ratios for ${ }^{68} \mathrm{Ga}-11$ (c) compared to the respective DOTA analogue ${ }^{68} \mathrm{Ga}-10$ (b). In agreement with the results obtained from the biodistribution (Figure 7), the metabolically stable ${ }^{68} \mathrm{Ga}-12$ (d) exhibits increased tumour accumulation and a lower unspecific whole body uptake and tumour-to-background ratios even higher than those of the reference compound $\left[{ }^{68} \mathrm{Ga}\right]$ HBED-CC-Ahx-KuE (a). That tracer uptake into tumour and kidneys is specific and PSMA mediated [18], as illustrated by the blocking experiment with PMPA $\left(8 \mathrm{mg} / \mathrm{kg}\right.$ ) (Figure $\left.8 \mathrm{~d}^{\prime}\right)$.

In addition, the biodistribution kinetics of ${ }^{68} \mathrm{Ga}-10$, ${ }^{68} \mathrm{Ga}-11,{ }^{68} \mathrm{Ga}-12$, and the reference compound $\left[{ }^{68} \mathrm{Ga}\right]$ HBED-CC-Ahx-KuE were investigated by carrying out dynamic $\mu$ PET scans over a period of $1.5 \mathrm{~h}$ in CD-1 nu/ nu mice bearing LNCaP tumour xenografts (Figure 9). Despite the somewhat lower individual tumour uptake of ${ }^{68} \mathrm{Ga}-12$ observed in this $\mu$ PET-study, the markedly enhanced clearance of this compound from non-target 
Table 2 Internalization of radiometalated ligands in percentage of external reference $\left(\left[{ }^{125} \mathrm{I}\right] \mathrm{I}-\mathrm{BA}\right) \mathrm{KuE}$

\begin{tabular}{|c|c|c|}
\hline Ligand & & $\begin{array}{l}\text { Internalization }(1 \mathrm{~h}) \\
\text { in } \% \text { of }\left(\left[{ }^{125} \mathrm{l}\right] \mathrm{-BA}\right) \mathrm{KuE}\end{array}$ \\
\hline 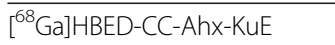 & & $91.1 \pm 1.7$ \\
\hline$\left[{ }^{68} \mathrm{Ga}\right] \mathrm{DOTA}$-FFK(Sub-KuE) & $\left({ }^{68} \mathrm{Ga}-10\right)$ & $14.6 \pm 0.8$ \\
\hline ["77Lu]DOTA-FFK(Sub-KuE) & $\left({ }^{177} \mathrm{Lu}-10\right)$ & $19.3 \pm 0.9$ \\
\hline$\left[{ }^{68} \mathrm{Ga}\right] \mathrm{DOTAGA-FFK}($ Sub-KuE) & $\left({ }^{68} \mathrm{Ga}-11\right)$ & $28.4 \pm 0.7$ \\
\hline${ }^{[77}$ Lu]DOTAGA-FFK(Sub-KuE) & $\left({ }^{177} \mathrm{Lu}-11\right)$ & $36.1 \pm 1.1$ \\
\hline$\left[{ }^{68} \mathrm{Ga}\right] \mathrm{DOT} A G A-f f k(S u b-K u E)$ & $\left({ }^{68} \mathrm{Ga}-12\right)$ & $42.5 \pm 1.7$ \\
\hline [177Lu]DOTAGA-ffk(Sub-KuE) & $\left({ }^{177} \mathrm{Lu}-12\right)$ & $44.4 \pm 1.8$ \\
\hline
\end{tabular}

Data is corrected for unspecific binding, $c=0.2 \mathrm{nM}$ for ${ }^{68} \mathrm{Ga}, c=0.5 \mathrm{nM}$ for

${ }^{177}$ Lu compounds, $37^{\circ} \mathrm{C}, 1 \mathrm{~h}, 125,000$ cells/well, PLL-coated plates.

tissues resulted in higher tumour-to-tissue ratios for ${ }^{68} \mathrm{Ga}-12$ compared to $\left[{ }^{68} \mathrm{Ga}\right] \mathrm{HBED}-\mathrm{CC}-\mathrm{Ahx}-\mathrm{KuE}$.

\section{Discussion}

Due to the consistent overexpression of PSMA in especially hormone-refractory and metastatic prostate cancer, this cell surface enzyme represents an excellent target for high-contrast PET imaging and also for therapeutic applications. The currently available PSMA-targeted radiopharmaceuticals are highly optimized either for imaging [36,37] or endoradiotherapeutic applications [25], but so far none of the compounds was evaluated for a theranostic concept. Our approach was therefore focused on the development of a PSMA ligand allowing for both, complexation with, e.g. ${ }^{68} \mathrm{Ga}$ or ${ }^{111} \mathrm{In}$ for PET or SPECT and with therapeutic $\mathrm{M}^{3+}$-radiometals, e.g. ${ }^{177} \mathrm{Lu},{ }^{90} \mathrm{Y}$ or ${ }^{225} \mathrm{Ac}$ for endoradiotherapy. The most frequently used chelator for this purpose is DOTA, and recently, a first KuE-based DOTA-conjugated PSMA inhibitor $\left({ }^{68} \mathrm{Ga}-10,[17]\right)$ has been described. In a comparative preclinical evaluation with $\left[{ }^{68} \mathrm{Ga}\right] \mathrm{HBED}$ CC-Ahx-KuE [18], ${ }^{68} \mathrm{Ga}-10$ showed significantly lower tumour uptake than $\left[{ }^{68} \mathrm{Ga}\right]$ HBED-CC-Ahx-KuE. However, since ${ }^{68} \mathrm{Ga}-10$ may be labelled with a broad palette of diagnostic and therapeutic radiometals, whereas $\left[{ }^{68} \mathrm{Ga}\right]$ HBED-CC-Ahx-KuE may not, we used ${ }^{68} \mathrm{Ga}-10$

Table 3 Lipophilicity of the radiolabelled ligands ( $\log P_{(o / w)}$; distribution coefficient in $\mathbf{n}$-octanol/PBS)

\begin{tabular}{llc}
\hline Ligand & & $\log \boldsymbol{P}_{(\mathbf{o} / \mathbf{w})}$ \\
\hline$\left[{ }^{68} \mathrm{Ga}\right]$ HBED-CC-Ahx-KuE & & $-4.1 \pm 0.1$ \\
{$\left[{ }^{68} \mathrm{Ga}\right]$ DOTA-FFK(Sub-KuE) } & $\left({ }^{68} \mathrm{Ga}-\mathbf{1 0}\right)$ & $-3.1 \pm 0.2$ \\
{$\left[{ }^{177} \mathrm{Lu}\right]$ DOTA-FFK(Sub-KuE) } & $\left({ }^{177} \mathrm{Lu}-\mathbf{1 0}\right)$ & $-2.7 \pm 0.02$ \\
{$\left[{ }^{68} \mathrm{Ga}\right]$ DOTAGA-FFK/ffk(Sub-KuE) } & $\left({ }^{68} \mathrm{Ga}-\mathbf{1 1 / 1 2}\right)^{\mathrm{a}}$ & $-3.6 \pm 0.1$ \\
$\left.{ }^{177} \mathrm{Lu}\right]$ DOTAGA-FFK/ffk(Sub-KuE) & $\left({ }^{177} \mathrm{Lu} \mathbf{1 1 1 / 1 2}\right)^{\mathrm{a}}$ & $-3.9 \pm 0.1$ \\
\hline
\end{tabular}

Data are expressed as mean \pm SD $(n=6) .{ }^{a}$ Determined for ${ }^{68} \mathrm{Ga}-11$ and ${ }^{177} \mathrm{Lu}-11$. as a starting point for the development of improved PSMA-targeted theranostics.

In a first attempt to improve the pharmacokinetics of the DOTA-coupled PSMA ligand 10, we increased the hydrophilicity of the ligand by substitution of DOTA by DOTAGA, resulting in 11. Although $\left[{ }^{68} \mathrm{Ga}\right] \mathrm{HBED}-\mathrm{CC}-$ Ahx-KuE contains the lipophilic HBED-CC chelator, which improves binding affinity [18], a $\log P$ of $-4.1 \pm 0.1$ was determined, revealing a significantly higher hydrophilicity compared to $\log P=-3.1 \pm 0.2$ for ${ }^{68} \mathrm{Ga}-10$. The hydrophilicity of the ${ }^{68} \mathrm{Ga}$-labelled DOTAGA-coupled ligand 11 increased to $\log P=-3.6 \pm 0.1$. For ${ }^{68} \mathrm{Ga}$, as well as ${ }^{177} \mathrm{Lu}$ labelling, the DOTA-conjugated ligand $\mathbf{1 0}$

\section{$\left[{ }^{68} \mathrm{Ga}\right] D O T A G A-F F K\left(\right.$ Sub-KuE) $\left({ }^{68} \mathrm{Ga}-11\right)$}
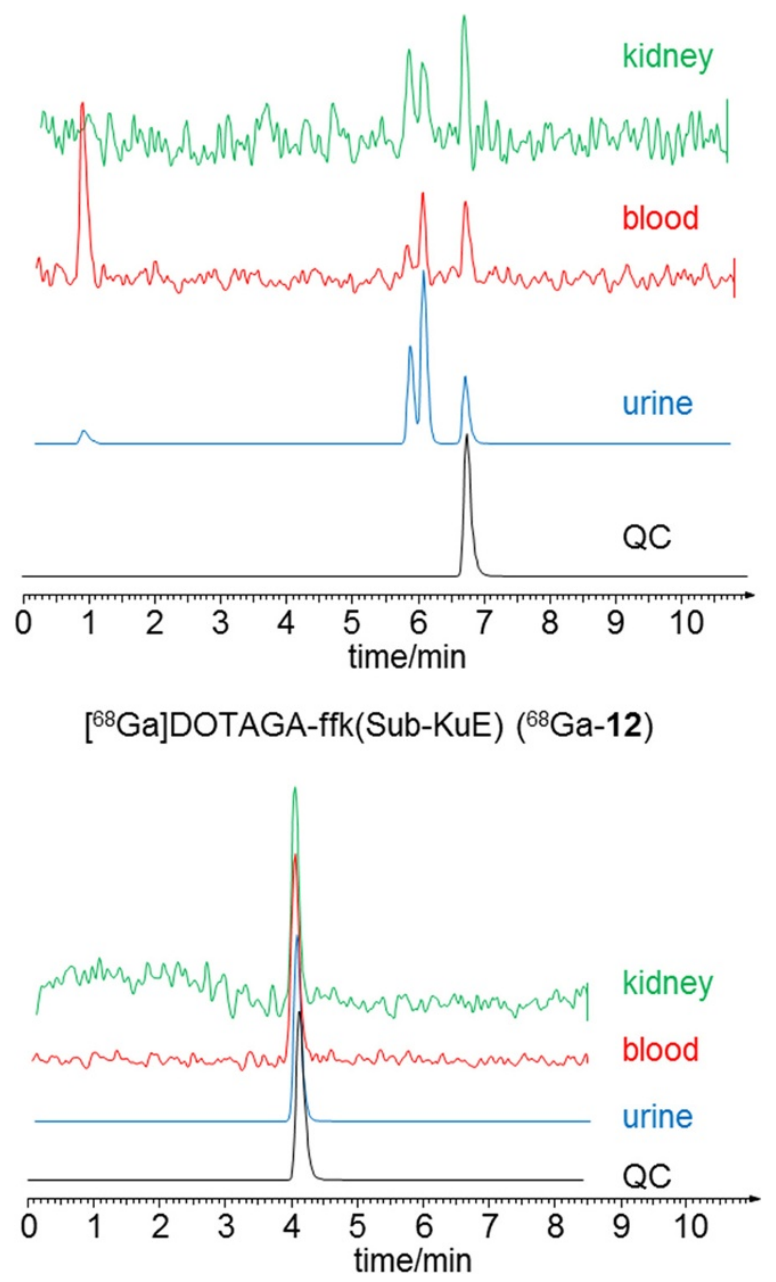

Figure 6 Exemplary radio-HPLC analyses of extracts from homogenized organs and body fluids. HPLC-traces of CD-1 nu/nu mice $\left(0.5\right.$ h p.i. of 40 to $45 \mathrm{MBq}$ of ${ }^{68} \mathrm{Ga}$ labelled tracer, Chromolith column, flow rate $3 \mathrm{~mL} / \mathrm{min}$ ) for ${ }^{68} \mathrm{Ga}-\mathbf{1 1}$ (3\% for $3 \mathrm{~min}, 3 \%$ to $95 \%$ in $6 \mathrm{~min}, 95 \%$ for $3 \mathrm{~min}$ ) and ${ }^{68} \mathrm{Ga}-\mathbf{1 2}$ (3\% to 95\% in $6 \mathrm{~min}, 95 \%$ for $3 \mathrm{~min})$. 


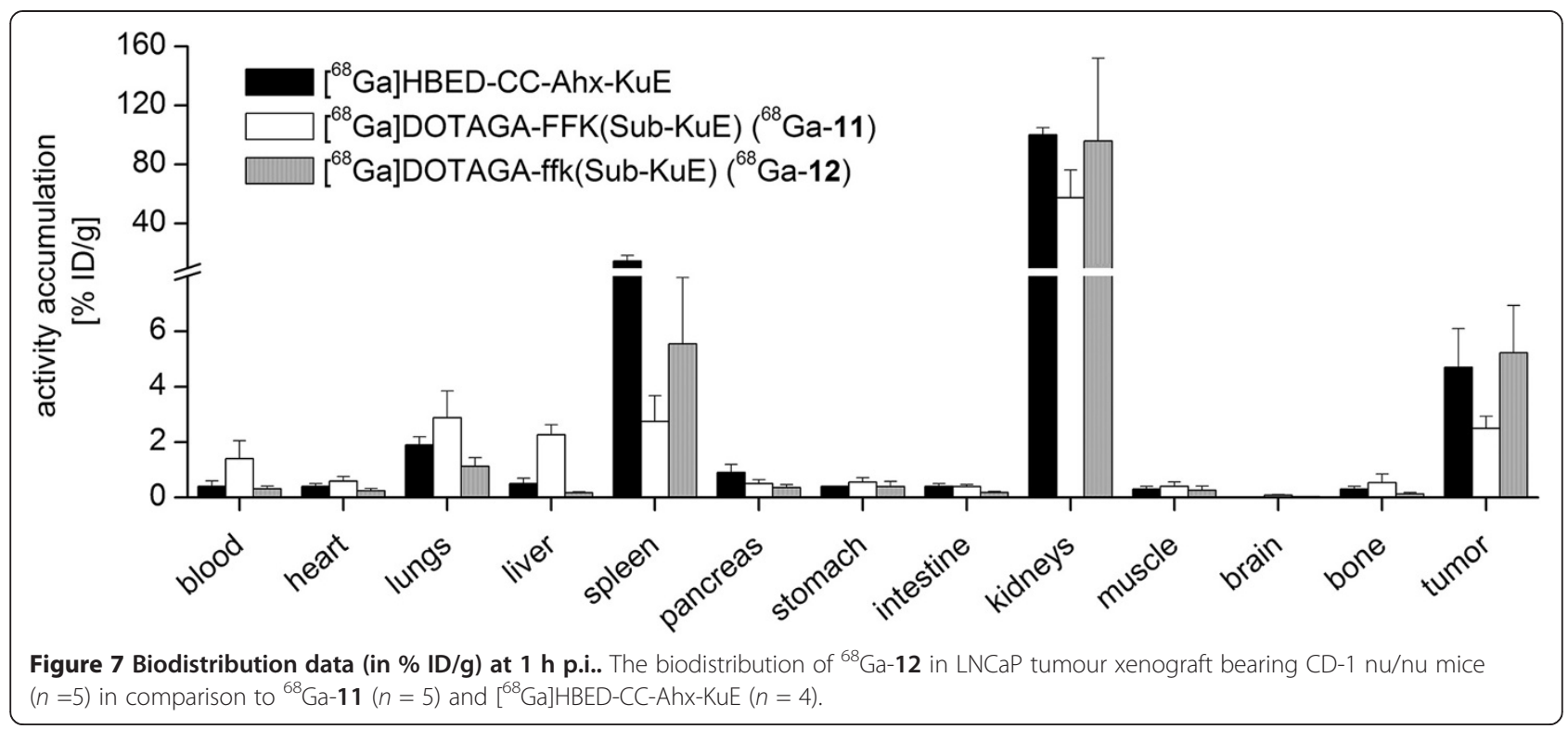

and the DOTAGA-conjugated ligands 11 and 12 exhibited no differences in labelling efficiency.

To examine the metabolic stability of these new PSMA tracers in vivo, CD-1 nu/nu mice were injected with the ${ }^{68}$ Ga-labelled ligand 11. Due to its L-amino acid spacer, ${ }^{68} \mathrm{Ga}-11$ was rapidly metabolized. Furthermore, we demonstrated that fast metabolization of ${ }^{68} \mathrm{Ga}-10$ and ${ }^{68} \mathrm{Ga}-11$ resulted in discontinuous clearance kinetics and low tumour accumulation in vivo (Figure 7, 8, 9). This most likely explains the finding in the literature, that despite moderate affinity towards PSMA ( $\left.\mathrm{IC}_{50}=29.5 \pm 6.6 \mathrm{nM}\right)$ the DOTA ligand ${ }^{68} \mathrm{Ga}-10$ exhibited unfavourable tumour targeting compared to $\left[{ }^{68} \mathrm{Ga}\right] \mathrm{HBED}-\mathrm{CC}-\mathrm{Ahx}-\mathrm{KuE}$. Further, we observed significant inter-individual differences in metabolization kinetics for ${ }^{68} \mathrm{Ga}-\mathbf{1 1}$ (with its L-amino acid spacer) in mice, which might explain inconsistent in vivo results obtained with PSMA ligands with L-amino acid spacers $[38,39]$. To overcome the problem of rapid proteolytic cleavage of radiolabelled 11, we substituted the Lamino acid spacer (FFK) by its D-amino acids counterpart ffk (12) resulting in high metabolic stability in vivo.

In addition to the improvement in metabolic stability for 12, we found that the DOTAGA-conjugated ligands 11 and 12, as well as their gallium(III) and lutetium(III) complexes, showed a significantly increased affinity towards PSMA on LNCaP cells compared to the DOTA-

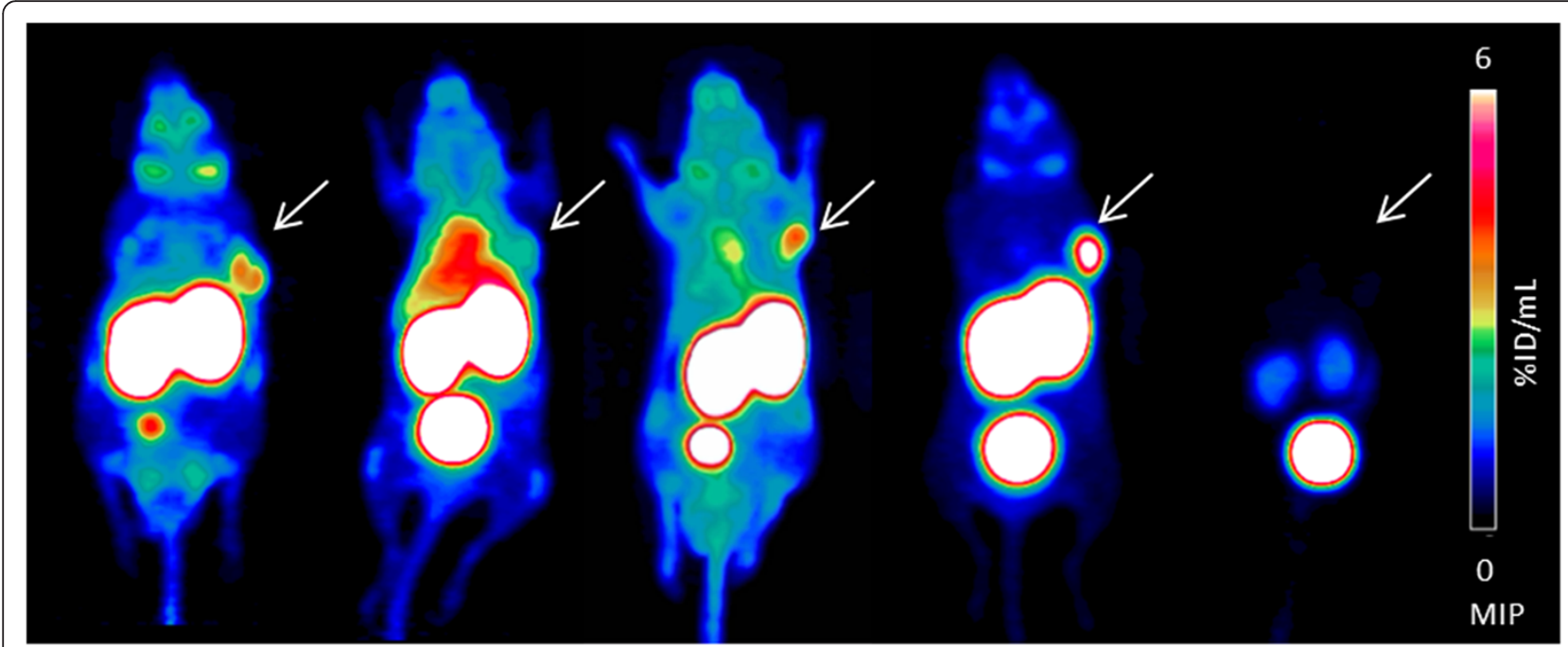

Figure 8 Maximum intensity projections (MIP) of $\mu$ PET scans. MIP (1 h p.i. for $15 \mathrm{~min}, 0 \%$ to $6 \% \mathrm{ID} / \mathrm{mL}$ ) of five LNCaP human prostate carcinoma xenograft bearing mice (right shoulder) after injection of approximately $15 \mathrm{MBq}$ (a) $\left[{ }^{68} \mathrm{Ga}\right] \mathrm{HBED}-\mathrm{CC}-\mathrm{Ahx}-\mathrm{KuE}$, (b) ${ }^{68} \mathrm{Ga}-\mathbf{1 0}$, (c) ${ }^{68} \mathrm{Ga}-\mathbf{1 1}$, (d) ${ }^{68} \mathrm{Ga}-\mathbf{1 2}$, (d') ${ }^{68} \mathrm{Ga}-\mathbf{1 2}+$ blocking (8 mg/kg PMPA). 


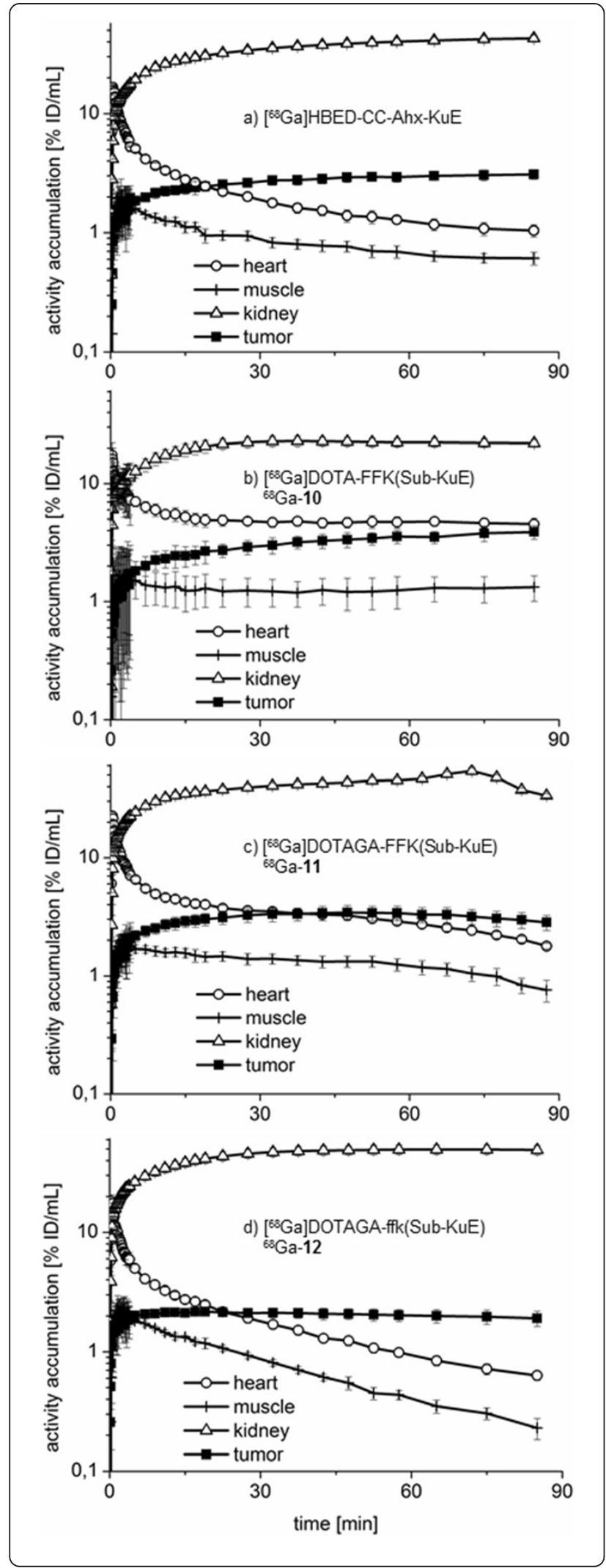

Figure 9 Time-activity-curves (logarithmic plot) in \% ID/mL for blood pool (heart), muscle, kidney and tumour. Graphs for (a) $\left[{ }^{68} \mathrm{Ga}\right] \mathrm{HBED}-\mathrm{CC}-\mathrm{Ahx}-\mathrm{KuE}$, (b) ${ }^{68} \mathrm{Ga}-10$, (c) ${ }^{68} \mathrm{Ga}-\mathbf{1 1}$, (d) ${ }^{68} \mathrm{Ga}-12$ are derived from dynamic small animal PET data.

coupled ligand $10 /{ }^{\text {nat }} \mathrm{Ga}-10 /{ }^{\text {nat }} \mathrm{Lu}-10$. Especially, ${ }^{\text {nat }} \mathrm{Lu}-$ $10\left(\mathrm{IC}_{50}=54.7 \pm 6.1 \mathrm{nM}\right)$ was less affine compared to ${ }^{\text {nat }} \mathrm{Lu}-11(15.1 \pm 1.5 \mathrm{nM})$ or ${ }^{\text {nat }} \mathrm{Lu}-12(13.1 \pm 2.2 \mathrm{nM})$. This finding most likely is due to the increased charge of the DOTAGA-ligands. In our competitive binding assay, unlike reported for other assays in the literature [18], a significantly lower affinity for ${ }^{\text {nat }} \mathrm{Ga}-10$ ( $\mathrm{IC}_{50}$ of $29.5 \pm$ $6.6 \mathrm{nM})$ was determined compared to $\left[{ }^{\text {nat }} \mathrm{Ga}\right] \mathrm{HBED}-\mathrm{CC}$ Ahx-KuE $\left(\mathrm{IC}_{50}=6.1 \pm 0.8 \mathrm{nM}\right)$.

As expected from their enhanced PSMA affinities, the DOTAGA ligands ${ }^{68} \mathrm{Ga} /{ }^{177} \mathrm{Lu}-\mathbf{1 1}$ and ${ }^{68} \mathrm{Ga} /{ }^{177} \mathrm{Lu}-\mathbf{1 2}$ showed up to twofold increased internalization compared to the corresponding DOTA ligands ${ }^{68} \mathrm{Ga} /{ }^{177} \mathrm{Lu}-$ 10. Interestingly, ${ }^{68} \mathrm{Ga} /{ }^{177} \mathrm{Lu}-12$ with the ffk spacer showed a higher internalization rate than ligand $\mathbf{1 1}$ with the FFK spacer. Blocking experiments with PMPA highlight the high PSMA-specificity of these tracers.

Accordingly, the pharmacokinetics and tumour uptake of the new ligands, i.e. ${ }^{68} \mathrm{Ga}-12$ in LNCaP-tumour bearing CD-1 nu/nu mice could be enhanced (Figure 7). The metabolically instable ${ }^{68} \mathrm{Ga}-11$ revealed higher activity levels in the blood pool and almost all organs, whereas the metabolically stable tracer ${ }^{68} \mathrm{Ga}-\mathbf{1 2}$ displayed no significant uptake in the gastrointestinal tract $(<0.5 \% \mathrm{ID} / \mathrm{g})$ and high kidney accumulation of $96 \pm 45 \% \mathrm{ID} / \mathrm{g}$. The kidney uptake is PSMA-specific, as shown in the blocking experiment (Figure 8d'). Although $\left[{ }^{68} \mathrm{Ga}\right] \mathrm{HBED}-\mathrm{CC}-\mathrm{Ahx}$ KuE showed a higher affinity and increased internalization rate compared to ${ }^{68} \mathrm{Ga}-12$, the in vivo biodistribution (Figure 7) and $\mu$ PET imaging studies (Figure 8) revealed favourable in vivo characteristics for ${ }^{68} \mathrm{Ga}-12$. The uptake of ${ }^{68} \mathrm{Ga}-12$ into the PSMA positive LNCaP tumour xenograft was somewhat increased compared to that of $\left[{ }^{68} \mathrm{Ga}\right]$ HBED-CC-Ahx-KuE $(5.2 \pm 1.2 \%$ vs. $4.7 \pm 0.2 \% \mathrm{ID} / \mathrm{g}$, respectively). Further, $\left[{ }^{68} \mathrm{Ga}\right] \mathrm{HBED}-\mathrm{CC}-\mathrm{Ahx}-\mathrm{KuE}$ showed enhanced tracer uptake into the lung $(1.9 \pm 0.4 \%$ vs. $1.1 \pm$ $0.3 \% \mathrm{ID} / \mathrm{g})$, liver $(0.5 \pm 0.1$ vs. $0.2 \pm 0.04 \% \mathrm{ID} / \mathrm{g})$, spleen $(14.7 \pm 2.6$ vs. $5.5 \pm 0.2 \% \mathrm{ID} / \mathrm{g})$ and pancreas $(0.9 \pm 0.2$ vs. $0.4 \pm 0.1 \% \mathrm{ID} / \mathrm{g})$. Therefore, the lower unspecific uptake of ${ }^{68} \mathrm{Ga}-12$ compared to $\left[{ }^{68} \mathrm{Ga}\right]$ HBED-CC-Ahx-KuE resulted in higher tumour-to-background ratios, i.e. tumour-toblood $(17.0 \pm 0.5$ vs. $12.5 \pm 0.7)$ and tumour-to-skeletal muscle $(19.8 \pm 0.7$ vs. $16.2 \pm 0.1)$.

After the initial distribution phase of a radiopharmaceutical, straightforward clearance kinetics is typically characterized by a linear decrease in a semilogarithmic plot (two-compartment model). Interestingly, this kinetic profile (Figure 9) was only observed for ${ }^{68} \mathrm{Ga}-12$, whereas 
all other tracers (or their radiolabelled metabolites) exhibit unspecific retention or redistribution effects, resulting in non-linear kinetics (e.g. between 10 and $60 \mathrm{~min}$ ) in the semilogarithmic plot. Considering the time-activity curves, it is worth noting that based on the kinetics of the reference compound $\left[{ }^{68} \mathrm{Ga}\right] \mathrm{HBED}-\mathrm{CC}-\mathrm{Ahx}-\mathrm{KuE}$ redistribution from tissues and compartments with unspecific uptake in the early phase seems likely and might explain the discontinuous clearance and increasing tumour uptake at later time points. The uptake of DOTA conjugate ${ }^{68} \mathrm{Ga}-10$ in the tumour is continuously increasing over time, but surprisingly without a corresponding decline of activity in muscle or blood (as measured over the heart). In contrast, a slow washout from the target and non-target tissues was observed for ${ }^{68} \mathrm{Ga}-11$. Most likely as a result of its metabolic instability, ${ }^{68} \mathrm{Ga}-11$ exhibited discontinuous and only moderate clearance kinetics. However, ${ }^{68} \mathrm{Ga}-12$ shows typical and nearly ideal in vivo pharmacokinetics, both for the target tissue (tumour and kidney) as well as the non-target tissue muscle and the blood. Equivalent to our DOTAGA ligand 12, the biodistribution of a naphthyl-containing $\left[{ }^{177} \mathrm{Lu}\right]$ DOTA-PSMA ligand was described recently [40], therefore, we assume that ${ }^{177} \mathrm{Lu}-\mathbf{1 2}$ also reveals favourable properties in vivo.

\section{Conclusions}

Compared to the metabolically unstable DOTA conjugate $\mathbf{1 0}$ and DOTAGA-conjugate $\mathbf{1 1},{ }^{68} \mathrm{Ga}$ - and ${ }^{177} \mathrm{Lu}-\mathbf{1 2}$ were found to be rapidly internalized into PSMA expressing cells, to have a favourable pharmacokinetic profile in vivo and only negligible unspecific uptake with no redistribution in vivo. Based on the DOTAGA chelator and the use of a D-amino acid spacer, compound $\mathbf{1 2}$ possesses remarkable potential for a PSMA based theranostics concept and is a suitable lead structure for the continuing development of PSMA ligands with further improved affinity.

\section{Competing interests}

The authors declare that they have no competing interests.

\section{Authors' contributions}

MW planned and carried out the synthesis, in vitro and in vivo evaluation. JS planned and optimized the radiolabelling and metabolite studies. MScho participated in the design and coordination of the experiments and helped with data interpretation. MW, JS and MScho drafted the manuscript. MSchw was involved in data interpretation and revised the manuscript. HJW initiated and designed the study, helped analysing and interpreting the data and revised the manuscript. All authors approved the final manuscript.

\section{Acknowledgement}

The research leading to these results has received funding from the Deutsche Forschungsgemeinschaft (DFG) under Grant Agreement No. SFB 824 project Z1. We thank Simon Schmied for synthetic assistance, Sybille Reder, Markus Mittelhäuser and Marco Lehmann for HPET imaging and Johannes Notni for editing the figures.

\section{Author details}

'Pharmaceutical Radiochemistry, Technical University Munich,

Walther-Meißner-Str. 3, 85748 Garching, Germany. ${ }^{2}$ Department of Nuclear Medicine, Technical University Munich (Klinikum rechts der Isar), Ismaninger Straße 22, 81675 München, Germany.

Received: 13 October 2014 Accepted: 6 November 2014

Published online: 25 November 2014

\section{References}

1. Mesters JR, Barinka C, Li W, Tsukamoto T, Majer P, Slusher BS, Konvalinka J, Hilgenfeld R: Structure of glutamate carboxypeptidase II, a drug target in neuronal damage and prostate cancer. EMBO J 2006, 25:1375-1384.

2. Ghosh A, Heston WD: Tumor target prostate specific membrane antigen (PSMA) and its regulation in prostate cancer. J Cell Biochem 2004, 91:528-539.

3. Silver DA, Pellicer I, Fair WR, Heston WD, Cordon-Cardo C: Prostate-specific membrane antigen expression in normal and malignant human tissues. Clin Cancer Res 1997, 3:81-85.

4. Pinto JT, Suffoletto BP, Berzin TM, Qiao CH, Lin S, Tong WP, May F, Mukherjee B, Heston WDW: Prostate-specific membrane antigen: a novel folate hydrolase in human prostatic carcinoma cells. Clin Cancer Res 1996, 2:1445-1451.

5. Carter RE, Feldman AR, Coyle JT: Prostate-specific membrane antigen is a hydrolase with substrate and pharmacologic characteristics of a neuropeptidase. Proc Natl Acad Sci USA 1996, 93:749-753.

6. Schulke N, Varlamova OA, Donovan GP, Ma D, Gardner JP, Morrissey DM, Arrigale RR, Zhan C, Chodera AJ, Surowitz KG, Maddon PJ, Heston WD, Olson WC: The homodimer of prostate-specific membrane antigen is a functional target for cancer therapy. Proc Natl Acad Sci USA 2003, 100:12590-12595.

7. Kozikowski AP, Nan F, Conti P, Zhang J, Ramadan E, Bzdega T, Wroblewska B, Neale JH, Pshenichkin S, Wroblewski JT: Design of remarkably simple, yet potent urea-based inhibitors of glutamate carboxypeptidase II (NAALADase). J Med Chem 2001, 44:298-301.

8. Pomper MG, Musachio JL, Zhang J, Scheffel U, Zhou Y, Hilton J, Maini A, Dannals RF, Wong DF, Kozikowski AP: ${ }^{11}$ C-MCG: synthesis, uptake selectivity, and primate PET of a probe for glutamate carboxypeptidase II (NAALADase). Mol Imaging 2002, 1:96-101.

9. Foss CA, Mease RC, Fan H, Wang Y, Ravert HT, Dannals RF, Olszewski RT, Heston WD, Kozikowski AP, Pomper MG: Radiolabeled small-molecule ligands for prostate-specific membrane antigen: in vivo imaging in experimental models of prostate cancer. Clin Cancer Res 2005, 11:4022-4028.

10. Chen Y, Foss CA, Byun Y, Nimmagadda S, Pullambhatla M, Fox JJ, Castanares M, Lupold SE, Babich JW, Mease RC, Pomper MG: Radiohalogenated prostate-specific membrane antigen (PSMA)-based ureas as imaging agents for prostate cancer. J Med Chem 2008, 51:7933-7943.

11. Mease RC, Dusich CL, Foss CA, Ravert HT, Dannals RF, Seidel J, Prideaux A, Fox JJ, Sgouros G, Kozikowski AP, Pomper MG: $N$-[N-[(S)-1,3-Dicarboxypropyl] carbamoyl]-4-[ $\left[{ }^{18}\right.$ F]fluorobenzyl-L-cysteine, $\left[{ }^{18} \mathrm{~F}\right] \mathrm{DCFBC}$ : a new imaging probe for prostate cancer. Clin Cancer Res 2008, 14:3036-3043.

12. Maresca KP, Hillier SM, Femia FJ, Keith D, Barone C, Joyal JL, Zimmerman CN, Kozikowski AP, Barrett JA, Eckelman WC, Babich JW: A series of halogenated heterodimeric inhibitors of prostate specific membrane antigen (PSMA) as radiolabeled probes for targeting prostate cancer. J Med Chem 2009, 52:347-357.

13. Hillier SM, Maresca KP, Femia FJ, Marquis JC, Foss CA, Nguyen N, Zimmerman CN, Barrett JA, Eckelman WC, Pomper MG, Joyal JL, Babich JW: Preclinical evaluation of novel glutamate-urea-lysine analogues that target prostate-specific membrane antigen as molecular imaging pharmaceuticals for prostate cancer. Cancer Res 2009, 69:6932-6940.

14. Banerjee SR, Foss CA, Castanares M, Mease RC, Byun Y, Fox JJ, Hilton J, Lupold SE, Kozikowski AP, Pomper MG: Synthesis and evaluation of ${ }^{99 \mathrm{~m}} \mathrm{Tc}$ and Re-labeled inhibitors of the prostate-specific membrane antigen (PSMA). J Med Chem 2008, 51:4504-4517.

15. Kularatne SA, Zhou Z, Yang J, Post CB, Low PS: Design, synthesis, and preclinical evaluation of prostate-specific membrane antigen targeted ${ }^{99 m}$ Tc-radioimaging agents. Mol Pharm 2009, 6:790-800. 
16. Zhang AX, Murelli RP, Barinka C, Michel J, Cocleaza A, Jorgensen WL, Lubkowski J, Spiegel DA: A remote arene-binding site on prostate specific membrane antigen revealed by antibody-recruiting small molecules. J Am Chem Soc 2010, 132:12711-12716.

17. Banerjee SR, Pullambhatla M, Byun Y, Nimmagadda S, Green G, Fox JJ, Horti A, Mease RC, Pomper MG: ${ }^{68} \mathrm{Ga}$-labeled inhibitors of prostate-specific membrane antigen (PSMA) for imaging prostate cancer. J Med Chem 2010, 53:5333-5341.

18. Eder M, Schafer M, Bauder-Wust U, Hull WE, Wangler C, Mier W, Haberkorn $\mathrm{U}$, Eisenhut $\mathrm{M:}{ }^{68} \mathrm{Ga}$-complex lipophilicity and the targeting property of a urea-based PSMA inhibitor for PET imaging. Bioconj Chem 2012, 23:688-697.

19. Akhtar NH, Pail O, Saran A, Tyrell L, Tagawa ST: Prostate-specific membrane antigen-based therapeutics. Adv Urol 2012, 2012:973820.

20. Milowsky MI, Nanus DM, Kostakoglu L, Sheehan CE, Vallabhajosula S, Goldsmith SJ, Ross JS, Bander NH: Vascular targeted therapy with anti-prostate-specific membrane antigen monoclonal antibody J591 in advanced solid tumors. J Clin Oncol 2007, 25:540-547.

21. Tagawa ST, Milowsky MI, Morris MJ, Vallabhajosula S, Christos PJ, Akhtar NH, Goldsmith SJ, Osborne J, Larson SM, Pandit-Taskar N, Scher HI, Bander NH, Nanus DM: Phase II study of Lutetium-177-labeled anti-prostate-specific membrane antigen (PSMA) monoclonal antibody J591 for metastatic castration-resistant prostate cancer. Clin Cancer Res 2013, 19:5182-5191.

22. Milowsky MI, Nanus DM, Kostakoglu L, Vallabhajosula S, Goldsmith SJ, Bander NH: Phase I trial of yttrium-90-labeled anti-prostate-specific membrane antigen monoclonal antibody $\mathrm{J} 591$ for androgen-independent prostate cancer. J Clin Oncol 2004, 22:2522-2531.

23. Hillier S, Merkin R, Maresca K, Zimmerman C, Barrett J, Tesson M, Eckelman W, Mairs R, Joyal J, Babich J: [ ${ }^{131}$ I]MIP-1375, a small molecule prostate-specific membrane antigen (PSMA) inhibitor for targeted therapy of prostate cancer (PCa). J Nucl Med 2011, 52(Supplement 1):361.

24. Hillier S, Rubino K, Maresca K, Marquis J, Tesson M, Zimmerman C, Eckelman W, Mairs R, Joyal J, Babich J: [ ${ }^{131}$ I]MIP-1466, a small molecule prostate-specific membrane antigen (PSMA) inhibitor for targeted radiotherapy of prostate cancer (PCa). J Nucl Med 2012, 53(Supplement 1):170.

25. Zechmann CM, Afshar-Oromieh A, Armor T, Stubbs JB, Mier W, Hadaschik B, Joyal J, Kopka K, Debus J, Babich JW, Haberkorn U: Radiation dosimetry and first therapy results with a ${ }^{124} \mid /{ }^{131}$-labelled small molecule (MIP-1095) targeting PSMA for prostate cancer therapy. Eur J Nucl Med Mol Imaging 2014, 41:1280-1292

26. Bernhard C, Moreau M, Lhenry D, Goze C, Boschetti F, Rousselin Y, Brunotte F, Denat F: DOTAGA-anhydride: a valuable building block for the preparation of DOTA-like chelating agents. Chemistry 2012, 18:7834-7841.

27. Eisenwiener KP, Powell P, Macke HR: A convenient synthesis of novel bifunctional prochelators for coupling to bioactive peptides for radiometal labelling. Bioorg Med Chem Lett 2000, 10:2133-2135

28. Heppeler A, Froidevaux S, Macke HR, Jermann E, Behe M, Powell P, Hennig M: Radiometal-labelled macrocyclic chelator-derivatized somatostatin analogue with superb tumour-targeting properties and potential for receptor-mediated internal radiotherapy. Chemistry 1999, 5:1974-1981.

29. Simecek J, Zemek O, Hermann P, Wester HJ, Notni J: A monoreactive bifunctional triazacyclononane phosphinate chelator with high selectivity for ${ }^{68} \mathrm{Ga}$. Chem Med Chem 2012, 7:1375-1378.

30. Schottelius M, Reubi JC, Eltschinger V, Schwaiger M, Wester HJ: N-terminal sugar conjugation and C-terminal Thr-for-Thr(ol) exchange in radioiodinated Tyr3-octreotide: effect on cellular ligand trafficking in vitro and tumor accumulation in vivo. J Med Chem 2005, 48:2778-2789.

31. Dekker B, Keen H, Shaw D, Disley L, Hastings D, Hadfield J, Reader A Allan D, Julyan $P$, Watson A, Zweit J: Functional comparison of annexin V analogues labelled indirectly and directly with iodine-124. NuCl Med Biol 2005, 32:403-413.

32. Vaidyanathan G, Zalutsky MR: Preparation of N-succinimidyl 3-[*1]iodobenzoate: an agent for the indirect radioiodination of proteins. Nat Protoc 2006, 1:707-713.

33. Martin R, Juttler $\mathrm{S}$, Muller M, Wester HJ: Cationic eluate pretreatment for automated synthesis of $\left[{ }^{68} \mathrm{Ga}\right]$ CPCR4.2. NuCl Med Biol 2014, 41:84-89.

34. Mueller D, Klette I, Baum RP, Gottschaldt M, Schultz MK, Breeman WA: Simplified $\mathrm{NaCl}$ based ${ }^{68} \mathrm{Ga}$ concentration and labeling procedure for rapid synthesis of ${ }^{68} \mathrm{Ga}$ radiopharmaceuticals in high radiochemical purity. Bioconj Chem 2012, 23:1712-1717.
35. Notni J, Simecek J, Hermann P, Wester HJ: TRAP, a powerful and versatile framework for ${ }^{68} \mathrm{Ga}$ radiopharmaceuticals. Chemistry 2011, 17:14718-14722.

36. Afshar-Oromieh A, Malcher A, Eder M, Eisenhut M, Linhart HG, Hadaschik BA, Holland-Letz T, Giesel FL, Kratochwil C, Haufe S, Haberkorn U, Zechmann CM: PET imaging with $a{ }^{68} \mathrm{Ga}$-labelled PSMA ligand for the diagnosis of prostate cancer: biodistribution in humans and first evaluation of tumour lesions. Eur J Nucl Med Mol Imaging 2013, 40:486-495.

37. Cho SY, Gage KL, Mease RC, Senthamizhchelvan S, Holt DP, Jeffrey-Kwanisai A, Endres CJ, Dannals RF, Sgouros G, Lodge M, Eisenberger MA, Rodriguez R, Carducci MA, Rojas C, Slusher BS, Kozikowski AP, Pomper MG: Biodistribution, tumor detection, and radiation dosimetry of ${ }^{18} \mathrm{~F}$-DCFBC, a low-molecularweight inhibitor of prostate-specific membrane antigen, in patients with metastatic prostate cancer. J Nucl Med 2012, 53(Supplement 1):1883-1891.

38. Baur B, Solbach C, Andreolli E, Winter G, Machulla HJ, Reske SN: Synthesis, radiolabelling and in vitro characterization of the ${ }^{68} \mathrm{Ga}$, ${ }^{90} \mathrm{Y}$ and ${ }^{177}$ Lu-labelled PSMA ligand, CHX-A"-DTPA-DUPA-Pep. Pharmaceuticals (Basel) 2014, 7:517-529.

39. Winter G, Zlatopolskiy B, Kull T, Bertram J, Genze F, Cudek G, Machulla H-J, Reske $\mathrm{S}:{ }^{68} \mathrm{Ga}$-DOTA-DUPA-Pep as a new peptide conjugate for molecular imaging of prostate carcinoma. J NuCl Med 2011, 52:1597.

40. Benesova M, Schaefer M, Bauder-Wuest U, Mier W, Haberkorn U, Eder M, Kopka K: Preclinical evaluation of a naphthyl-containing DOTAconjugated PSMA inhibitor with improved targeting and pharmacokinetic properties. Eur J Nucl Med Mol Imaging 2014, 2(Supplement):438.

doi:10.1186/s13550-014-0063-

Cite this article as: Weineisen et al: Synthesis and preclinical evaluation of DOTAGA-conjugated PSMA ligands for functional imaging and endoradiotherapy of prostate cancer. EJNMMI Research 2014 4:63.

\section{Submit your manuscript to a SpringerOpen ${ }^{\odot}$ journal and benefit from:}

- Convenient online submission

- Rigorous peer review

- Immediate publication on acceptance

- Open access: articles freely available online

- High visibility within the field

- Retaining the copyright to your article

Submit your next manuscript at $>$ springeropen.com 